\title{
Expedient behaviour and predetermination at the Ciota Ciara cave (north-western Italy) during Middle Palaeolithic.
}

Sara Daffara 0000-0001-7150-0289 (a, b) , Gabriele L.F. Berruti 0000-0002-8637-4585 ${ }^{(\mathrm{a}, \mathrm{b}, \mathrm{c})}$, Marta Arzarello 0000-0003-3379-1112 (a)

a) Dipartimento di studi umanistici, Università degli studi di Ferrara, Corso Ercole I d'Este 32, 44121 Ferrara, Italy

b) Associazione culturale 3P - Progetto Preistoria Piemonte, Via Lunga 38, 10099 San Mauro T.se (TO), Italy

c) Museo di Archeologia e Paleontologia “C. Conti”, Via Combattenti 5, 13011 Borgosesia (VC), Italy.

\section{Corresponding author}

Sara Daffara - Dipartimento di studi umanistici, Università degli studi di Ferrara, Corso Ercole I d'Este 32,44121 Ferrara, Italy - dffsra@unife.it

\begin{abstract}
The Ciota Ciara cave is a Middle Palaeolithic site located in Piedmont (north-western Italy) and it is the only one systematically investigated in the region. It opens at $670 \mathrm{~m}$ a.s.l. on the west side of Monte Fenera and its archaeological deposit has a stratigraphic sequence documenting several and repeated human frequentations. Four archaeological layers have been identified (13, 14, 15 and 103) and are characterized by lithic assemblages where vein quartz is the main exploited raw material. The upper level (13), was already subject to technological and functional studies but the enlargement of the excavated area made necessary a completion of the technological data. The aim of this work is to deal with a complete technological and functional study of the lithic assemblage of the four archaeological layers of the Ciota Ciara cave to face the issues of predetermination and adaptation of the reduction sequences to the raw materials features. The technological analysis is based on the concept of chaîne opératoire and refers to the classical definitions of the S.S.D.A., discoid and Levallois methods for the identification of the different exploitation strategies. The concepts of curated and expedient technology are also applied to the present study. We finally refer to the huge debate concerning the concept of predetermination related to cores that show reduced or none phases of core configuration for the analysis and interpretation of the considered lithic assemblage.

The results obtained show that the general behaviour can be interpreted as expedient, both from a technological and a functional point of view. The Middle Palaeolithic hunter-gatherers of the Ciota Ciara cave adapted their "technological background" to the resources available and put into action flexible adaptation strategies. Even in the shortness or absence of phases of core configuration, predetermination can be observed in the adaptation of Levallois and discoid concepts to the natural constraints of the pebbles chosen as cores. The natural convexities are exploited to obtain Levallois and discoid flakes after an intentional choice made by the knappers. In order to deeply investigate the characteristics of the technological behaviour of the hunter-gatherers that inhabited the site, the use-wear analysis is a fundamental additional source of information and it is here aimed to understand if there is or not a differential use of the lithic artefacts according to their typology and/or to the knapping method.
\end{abstract}

\section{Keywords}

Ciota Ciara, Levallois, vein quartz, use-wear analysis, technological behaviour. 


\section{Introduction}

The characteristics of an expedient technological behaviour was first proposed by L. Binford (1979) and defined as a poorly organized productive procedure, highlighting the criteria of technological investment as the main distinction between curated and expedient behaviours. Starting from this definition, several scholars focused on the criteria necessary to define a lithic assemblage as curated (e.g. Andrefsky Jr., 2009; Bamforth, 1986; Keeley, 1982; Kuhn, 1992; Odell, 1996; Riel-Salvatore and Barton, 2004; Shott, 1996), but just in recent studies the importance of what we intend as expedient behaviour has been pointed out (Romagnoli, 2015; Vaquero and Romagnoli, 2017). According to Vaquero and Romagnoli (2017) expedient assemblages can be defined as the result of low-cost technologies: almost exclusive use of local raw materials, reduction sequences aimed at the production of low-predetermined flakes, scarce presence of simple retouched tools.

On the other hand, the concept of predetermination, i.e. the production of flakes with specific characteristics, in Middle Palaeolithic lithic technology is traditionally linked to Levallois exploitation strategies and to the specific core configuration proper of this method, where the preparation of the lateral and distal convexities gives the knapper a good degree of control over the results of the knapping activity (Boëda, 1994; Boëda et al., 1990; Picin et al., 2014; Shimelmitz and Kuhn, 2018). According to E. Boëda (1994), the Levallois method is defined by the presence on the core of two hirarchized surfaces not equally convex and the production develops according to the exploitation of surfaces through a débitage direction that is parallel to the plan of intersection between the striking platform and the knapping surface.

The problems linked to the identification of predetermined reduction strategies on cores that do not show phases of core configuration has already been highlighted (Chazan, 1997; Dibble and BarYosef, 1995) but not deeply investigated. It is also known that the mechanical properties of a lithic raw material affect its response to knapping, the way in which the reduction sequences are performed and the characteristics of the products for what concerns integrity, dimensions and general morphology (e.g. Colonge and Mourre, 2006; de Lombera-Hermida and Rodriguez Rellan, 2010; Mourre, 1996, 1994). The use of raw materials like vein quartz in Palaeolithic sites is quite recurring, but the description of the technological adaptation applied for their exploitation is often inaccurate, thus attributing to non-flint reduction sequences the character of archaic, rough and notcurated production systems (de Lombera-Hermida and Rodríguez-Rellán, 2016; Rodríguez-Alvarez, 2016; Rodríguez-Rellan, 2016). In several European Middle Palaeolithic sites, a differential use of the lithic raw materials collected has been observed (e.g. Delagnes and Meignen, 2006; Faivre et al., 2014; Jaubert and Farizy, 1995; Rios-Garaizar et al., 2015; Romagnoli et al., 2016; Wiśniewski, 2014): according to the better or worse aptitude for knapping, they have been used for Levallois or discoid/centripetal/opportunistic reduction sequences, driving some authors to suppose a strict correlation between Levallois knapping sequences/good quality raw materials and between discoid/centripetal knapping sequences/low-quality raw materials.

The technological analysis of the lithic assemblage of the Ciota Ciara cave (north-western Italy), where most of the lithic artefacts are made on vein quartz, allow to face the issues of predetermination and adaptation of the reduction sequences to the raw materials features. The usewear analysis is instead an important source of information and it is here directed towards the identification of a possible differential use of the lithic artefacts according to their typology or to the knapping method.

\section{The site}

The Ciota Ciara cave is a still active karst cave located in Piedmont (north-western Italy). It is part of Monte Fenera's karst, an isolated relief ( $899 \mathrm{~m}$ a.s.l.) placed at the entrance of the Sesia valley (Fig. 1). The cave opens on the west side of Monte Fenera at $670 \mathrm{~m}$ a.s.l. and it can be accessed both from a big triangular entrance, facing south-west (665 $\mathrm{m}$ a.s.1.) and from a secondary entrance facing west (670 $\mathrm{m}$ a.s.1.) (Brecciaroli Taborelli, 1995; Fedele, 1966). The cave develops over more than $80 \mathrm{~m}$ on its principal axe, with a positive difference in height of $15 \mathrm{~m}$ from the main entrance 
to the bottom. The archaeological interest of the Ciota Ciara cave is known since the beginning of the XXth century (Conti, 1931) but systematic investigations started just in the 60s when some test pits were realized in the cave (Fig. 2) (Busa et al., 2005; Fedele, 1972, 1966; Gambari, 2005). In the $90 \mathrm{~s}$, two brief excavation campaigns took place after the finding of two teeth within sediments transported outside the cave by water and attributed to H. neanderthalensis (Busa et al., 2005; Gambari, 2005; Villa and Giacobini, 2005, 1993). The investigated area was located in the atrial part of the cave, the same where systematic and multidisciplinary researches started again in 2009 and they are still on-going (Fig. 2). Differently from the previous interventions, during the current excavations each remain with a length $\geq 2 \mathrm{~cm}$ is positioned, while sieving allows to recover the smallest lithic or faunal remains. After the restoration of previous excavations, new excavations focuses in the atrial part of the cave where a $2 \mathrm{~m}$ thick sequence was unearthed (Angelucci et al., 2018). Four main stratigraphic units have been identified $(13,14,15,103)$, each one corresponding to different modalities of frequentation of the site (Fig. 3) (Angelucci et al., 2018; Arzarello et al., 2012; Daffara et al., 2019, 2014). The paleo-environmental reconstruction, achieved through the paleontological analysis of macro and micro mammals remains, shows that a woodland environment was predominant during the frequentation of the site but a slight climatic change is visible between level 13 and 14, from warmer to cold and humid environments: level 14 is characterized by different markers of cold climate like Cricetus cricetus, Microtus cf. gregalis and Chionomys nivalis thus indicating an open woodland environment with exposed rocks (Berto et al., 2016). The large mammals' assemblage is dominated by carnivore remains in all the units (Ursus spelaeus, Ursus arctos, Canis lupus, Vulpes vulpes, Meles meles, Martes martes, Lynx lynx, Panthera leo and Panthera pardus), while the importance of herbivores (Rupicapra rupicapra, Cervus elaphus, cf. Dama, Bos primigenius, Bos sp., Bos vel. Bison, Sus scrofa, Stephanorinus sp.) increases in level 14 (Berto et al., 2016; Cavicchi, 2018). Cut marks related to skinning activities and flesh extraction are attested on some Ursus spelaeus remains (Buccheri et al., 2016). Preliminary numerical dating results indicate that the human frequentation of the Ciota Ciara cave may date to the second half of the Middle Pleistocene (Vietti, 2016). During the last two years, a new excavation area was opened in the interior part of the cave (Fig. 2). After the removal of reworked sediments deposited by water and coming from the interior of the cave, an archaeological layer corresponding to level 13 has been identified on an area of $7 \mathrm{~m}^{2}$ that is now under investigation.

\section{Materials and methods}

\subsection{Materials}

The technological analysis concerns the lithic assemblage coming from the atrial part of the Ciota Ciara cave, counting 7106 lithic artefacts (Tab. 1). It represents the most important Middle Palaeolithic lithic assemblage of the region and the only one issued from systematic and modern excavations. Therefore, its study represents a fundamental evidence to understand the economic and technological behaviour of the hunter-gatherers that occupied Piedmont during Middle Palaeolithic. The intense use of vein quartz, not only for opportunistic reduction sequences but also to produce predetermined tools through Levallois and discoid methods (Boëda, 1994, 1993), gives the chance to deeply analyse which adaptation strategies have been adopted for the exploitation of this raw material. A precise definition of the technological behaviour related to predetermined reduction strategies and its comparison to the ones adopted for opportunistic exploitation is performed, as to achieve a more detailed understanding of the general technological behaviour of the human groups that inhabited the cave during Middle Palaeolithic.

The functional analysis concerns a selected sample (Tab. 2) of 73 lithic artefacts from level 14 issued from opportunistic, Levallois and discoid reduction strategies and made of different raw materials: vein quartz, spongolite and flint. Excluding the lithics collected through sieving, the total amount of lithic artefact within which the sample has been selected is composed by 489 flakes and 
formal tools. For the aims of this work, we will also refer to data of level 13, already presented in Daffara et al. (2014). Levels 15 and 103 are not included in the functional analysis because the lithic artefacts are strongly affected by post depositional alterations, thus preventing the identification of use-wear traces.

Among the exploited raw materials, spongolite is quite particular. It is a sedimentary rock that outcrops in the Monte Fenera area and it is mainly composed by fossil remains of siliceous sponges (spicules); it is fine-grained and characterized by homogeneous texture and by high hardness with conchoidal fracture. In the archaeological record of the Ciota Ciara cave, two main kind of spongolite are present, characterized by a more or less pronounced porosity respectively (Berruto 2011). Both these varieties are rich in internal fracture planes that strongly affect the results of the knapping activities.

\subsection{Methods}

\subsubsection{Technological study}

The technological study of the lithic assemblage of the Ciota Ciara cave is based on the concept of chaîne opératoire (Geneste, 1991; Leroi-Gourhan, 1964; Pelegrin et al., 1988; Tixier, 1978). The first step of analysis corresponds to the technological reading of each object (core, flake, retouched tool, debris). Then, an additional level was the authentication of the relationship of the different products of the chaîne opératoire. For flakes, different technological features have been considered: characteristics of the butt and the ventral face, sizes, presence and types of knapping accidents. For vein quartz, we refer to specific works about the knapping stigmata and rate and modalities of fragmentation (Colonge and Mourre, 2006; de Lombera-Hermida, 2009; Di Modica and Bonjean, 2009; Driscoll, 2011; Manninen, 2016; Mourre, 1996; Tallavaara et al., 2010).

Retouched tools have been classified according to the typological list developed by Bordes (1961). The direction of the scars on the upper face and the presence and position of natural surfaces were used to identify the knapping methods and the phases of core reduction. The definition of each method is based on Forestier (1993) for S.S.D.A. (Système par surface de débitage alterné) reduction sequences and on Boëda $(1994,1993)$ for Levallois and discoid methods. Concerning these last two knapping methods, we also refer to other specific works discussing issues and problems linked to their definition and identification (Chazan, 1997; de Lombera-Hermida et al., 2016; Dibble and Bar-Yosef, 1995; Moncel et al., 2020; Peresani, 2003; Rodríguez-Rellan, 2016).

\subsubsection{Use-wear analysis}

Functional analysis began with the preliminary evaluation, at the naked eye and with a stereomicroscope, of all the lithic assemblage of level 14, excluding cores, debris and lithics from sieving. After this preliminary evaluation, the sample was composed by 73 debitage products (Tab. 2). Each selected artefact was gently washed with warm water and soap, then washed for 3 minutes in a mixture of demineralized water (75\%) and alcohol (25\%) in an ultrasonic tank and open-air dried. The use-wear analysis was completed with an integrated approach that uses the low power approach (Odell, 1981) combined with the high power approach (Keeley, 1980). Several works (e.g. Beyries, 1987; Clemente-Conte and Gibaja Bao, 2009; Cruz and Berruti, 2015; Igreja, 2009; Lemorini et al., 2014b; Moss, 1983; Van Gijn, 2014; Wilkins et al., 2015) show that the use of both the methodologies is more effective and productive. This methodology was applied to provide a more detailed understanding of the activities carried out with the lithic artefacts and to support the diagnosis of the processed materials (e.g. Keeley, 1980; Lemorini et al., 2014a, 2006; Rots, 2010; Van Gijn, 2014).

We refer to specific studies to accurately recognize the microwear attributes useful to infer the materials worked with vein quartz tools (e.g. Igreja, 2009; Knutsson et al., 2015; Knutsson and Lindé, 1990; Lemorini et al., 2014a; Márquez et al., 2016). 
For the analysis were used different microscopes: a stereomicroscope: Seben Incognita III with magnification from 20x to 80x, a stereomicroscope Leica Ez4 HD with magnification from 8x to $35 \mathrm{x}$ and a metallographic microscope Optika B 600 Met, with oculars 10x, 5 objectives PLAN IOS MET (5-10-20-50-100x), polarizing filters and bright and dark field equipped with a digital camera Optika B5. To reduce the intensity of the glare, typical of vein quartz (e.g. Clemente-Conte and Gibaja Bao, 2009; Igreja, 2009; Lemorini et al., 2014a) the metallographic microscope was equipped with a Differential Interference Contrast Microscopy (also known as Nomarski filter) (Igreja, 2009; Knutsson et al., 2015).

The pictures were taken with the software of the camera described above, while the Adobe Photoshop CS6 Portable (C) Adobe) software was used for image processing since it allows a single image to be built up from several photos taken at different depths of field.

\subsubsection{The experimental collection}

In order to perform a good analysis of the lithic assemblage, an experimental collection, including vein quartz, spongolite and flint artefacts created in 2011 by the authors, was used as comparison for the identification of the use-wear traces on the archaeological materials. This collection has been already employed for the use-wear analysis of the lithic artefacts of level 13 (Berruti and Arzarello, 2012; Daffara et al., 2014). The experiments were conducted on a wild boar carcass for skinning and butchering activities, skin and bone processing (Fig. 4). The experimental protocol performed aims to standardise the operations and to minimize the variables of the process, like time of use and number of actions carried out: each experimental item was used to perform a single action for five or ten minutes.

Vein quartz and spongolite have been collected in secondary position at the base of Monte Fenera and close to the primary outcrops respectively, from the same areas whence, according to the studies completed, they were collected by the human groups frequenting the cave (Daffara et al., 2019). During the experimental work, unretouched flakes issued from opportunistic reduction sequences were used. For each of them, the time of use, the direction of the gesture and the material worked were recorded (Tab. 3). After the experiments, each artefact was carefully washed with warm water and soap, and then it was washed for three minutes in a mixture of demineralized water (75\%) and alcohol (25\%) in an ultrasonic tank and open air dried. Each artefact was observed and analysed in three steps: macroscopically at the naked eye, with a stereomicroscope Seben Incognita III with magnification from 20x to 80x and with a microscope Optika B 600 Met with five objectives PLAN IOS MET (5-10-20-50-100x).

A further vein quartz experimental collection, realized in 2015 by one of the authors, was also considered for the aim of this work. It consists of unretouched vein quartz flakes used to perform different actions (i.e. cutting and scraping) on fresh and dry bone, dry and fresh wood, dry antler (Daffara et al., 2018). The experimental protocol adopted is the same described above.

\section{The lithic assemblage of the Ciota Ciara cave}

The lithic assemblage of the Ciota Ciara cave is composed by 7106 lithic artefacts coming from SS.UU. 13, 14, 15 and 103 (Tab. 1). In all the archaeological layers, the most exploited raw material is vein quartz $(70,6 \%)$ followed by local varieties of chert (spongolite $-21,1 \%$ and grey flint $4,9 \%$ ) and by other local raw materials sporadically attested in all the considered levels (Tab. 4). Allochthonous raw materials are also attested and represented by rhyolite and radiolarite (Tab. 4). Rhyolite was collected in secondary position at about $2 \mathrm{Km}$ in a straight line from the Ciota Ciara cave, on the opposite side of the Sesia valley, probably during movements linked to subsistence activities. The radiolarite exploited at the Ciota Ciara cave comes from outcrops and secondary deposits located at about $25-30 \mathrm{Km}$ from the site, probably during seasonal movements (Daffara et al., 2019). Concerning local raw materials, vein quartz was collected in secondary deposits located at the base of the mount; spongolite slabs and block are still available a few hundred meters from the cave; grey flint outcrops on the mount at about $720 \mathrm{~m}$ a.s.l.; other local rocks attested in the site 
like hyalite, jasper and milonite are present on Monte Fenera at different altitudes (Daffara et al., 2019).

\subsection{State of preservation}

The state of preservation of the lithic assemblage is generally good in all the considered units, even if some differences are visible due to the post depositional phenomena that affected the deposit. Lithics from level 15 are often affected by post depositional surface modifications of mechanical origin: as already pointed out by geoarchaeological analysis (Angelucci et al., 2018), in this level quite intense post depositional phenomena took place, mainly linked to water circulation. Therefore, $50 \%$ of vein quartz artefacts and $46 \%$ of artefacts issued from other raw materials are affected by rounding. Strong transport phenomena are linked to the deposition of unit 103 where mechanical post depositional alterations affect $26,4 \%$ of vein quartz artefacts and $43,8 \%$ of the other lithic implements (Angelucci et al., 2018; Daffara, 2017). Chemical alterations are present on flint, spongolite and radiolarite artefacts in different proportions in the considered levels: $25,2 \%$ in S.U. $13 ; 27,1 \%$ in S.U. $14 ; 45,4 \%$ in S.U. $15 ; 30,8 \%$ in S.U. 103. However, the intensity of these post depositional surface modifications is not so strong to prevent the technological analysis. The rate of fragmentation is quite high in all the considered levels (Tab. 5), as frequently observed in vein quartz assemblages (e.g. Colonge and Mourre, 2006; Tallavaara et al., 2010): complete flakes represent just the $28,8 \%$ of the lithic assemblage, while $15,3 \%$ of the knapping products are defined as incomplete flakes, showing small fractures often in the proximal part of the flake and due to debitage (Tab. 5).

\section{Results}

\subsection{Technological overview}

The reduction sequences performed at the Ciota Ciara cave are those typical of Middle Palaeolithic sites: opportunistic, discoid and Levallois, combined with a sporadic presence of a Kombewa s.l. debitage (Inizan et al., 1999; Tixier and Turq, 1999). The presence of cores and debris (i.e. shapeless fragments of various sizes) indicates that the knapping activities took place in the site for the main raw materials (vein quartz, spongolite, grey flint) while the other local rocks where probably knapped out of the site.

Neocortical surfaces are often present on the dorsal faces of the debitage products, regardless the knapping method (Tab. 6). This is particularly evident for vein quartz and spongolite, suggesting that the exploitation of these rocks started directly from their natural surfaces, taking advantage of the convexities already present on the blanks chosen as cores.

Unipolar knapping scars are predominant on the dorsal faces of the flakes (Tab. 7) and, according to the characteristics observed on cores (see section 5.1.1), they can be associated with opportunistic reduction strategies; following the same criteria, also orthogonal and bipolar knapping scars are supposed to belong to the opportunistic part of the lithic assemblage. Centripetal and crossed negatives are instead identified on Levallois and discoid flakes: concerning crossed negative, it has been observed that they could also belong to multidirectional (i.e. opportunistic) reduction sequences. Even if the application of further criteria, like presence of lateral and/or distal plungings, debitage direction and characteristics of the butts, led to a reliable classification of the products with crossed negatives, a small proportion remains indeterminate concerning the knapping method; other factors affecting the technological analysis were the state of preservation and the high rate of fragmentation. Indeterminate products represent $3,8 \%$ in level $13,9,8 \%$ in level $14,10 \%$ in level 15 and $11 \%$ in level 103.

Rhyolite and radiolarite are instead complementary lithic resources, brought in the site as finished tools which edges have been intensively rejuvenated, as shown by the presence of several retouch flakes in the assemblage. Except for rhyolite and radiolarite tools, retouch is barely attested in the Ciota Ciara cave lithic assemblage, it is always marginal and aimed to obtain denticulates, notches 
and different kind of scrapers. There are no visible qualitative or quantitative differences in the use of retouching depending on the knapping method.

According to the technological characteristics of products and cores, it is evident that all the main raw materials were exploited in the same way (Tabs. 8, 9, 10,11): between 40 and 50\% of the considered lithic assemblages is represented by cores and flakes belonging to opportunistic reduction strategies; the discoid method is well attested in the unifacial and bifacial modalities (SU $13=5,1 \%$; SU $14=8,5 \%$; SU $15=6,4 \%$; SU $103=4,8 \%$ ) as well as the Levallois method, present in the lineal and recurrent centripetal modalities in all the considered archaeological levels (SU $13=$ $1,3 \%$; SU $14=4,5 \%$; SU $15=3,9 \%$; SU $103=1,4 \%$ ).

\subsubsection{Opportunistic reduction strategies}

Opportunistic reduction sequences are clearly predominant in all the levels and for all the raw materials (Tabs. 8, 9, 10, 11). Vein quartz opportunistic exploitation starts with the choice of cores with suitable convexities, i.e. fluvial pebbles, decimetric blocks or big flakes (Fig. 5). The characteristics of the butts suggest that neocortical or flat surfaces (i.e. natural fracture surfaces occurred during fluvial transport) were preferentially chosen as striking platforms. Reduction sequences are generally short, and cores are discarded before their complete exhaustion. In most cases just two adjacent, orthogonal or, rarely, opposed striking platforms are exploited and when the convexities suitable for knapping are exhausted the core is abandoned. Multidirectional exploitation strategies are a minority within the considered assemblage, mainly due to the occurrence of fractures during knapping caused by internal flaws or cleavages. Each striking platform is exploited to obtain a limited number of products, usually no more than two or three. Vein quartz opportunistic flakes have triangular section and pronounced thickness, that can be interpreted as an adaptation to the raw material: as demonstrated by recent experimental studies, increasing thickness is a good strategy to avoid the occurrence of fractures (de Lombera-Hermida and Rodríguez-Rellán, 2016; Driscoll, 2011; Tallavaara et al., 2010). Opportunistic reduction strategies are clear also for spongolite (Fig. 5), while the low number of cores and products for the other raw materials does not allow to make reliable hypothesis. The characteristics of the butts suggest that also for spongolite the exploitation starts from flat surfaces naturally present on the cores. Spongolite cores are centimetric slabs ( $\leq 10 \mathrm{~cm}$ length) rich in internal parallel cleavage planes that can strongly affect the characteristics of the final products. These slabs are usually exploited according to their thickness, perpendicularly as regard to the cleavage planes. Even if a specific experimental study has not been performed yet, it is reliable to suppose that the systematic occurrence of this technological behaviour is due to an adaptation of the knapping sequences to the raw materials features. The initial morphology of the core strongly influences the dimensional properties of the final products. The thickness of the flakes is generally high, further consequence of the cores' morphology: spongolite slabs present knapping angles close to $90^{\circ}$ thus forcing knappers to hit the striking platform far from the core's edges. Due to raw material constraints, most of the cores present just one or two opposite striking platform, exploited till the exhaustion of the natural convexity to obtain a low number of products before their abandonment.

\subsubsection{Levallois reduction strategies}

Levallois reduction strategies are documented all along the sequence at the Ciota Ciara cave (Tabs $8,9,10,11)$ and two Levallois modalities are present: lineal and recurrent centripetal Levallois (Fig. 6).

In level 13 Levallois technology is applied on vein quartz and spongolite but just on vein quartz the reduction sequences are complete. Two vein quartz Levallois cores are present in this level (Tab. 8), belonging to the recurrent centripetal Levallois and to the preferential modality respectively. The recurrent centripetal core has a natural striking platform, part showing a neocortical surface, the other consists in natural fracture planes; one of the lateral convexities of the knapping surface has been prepared through two short centripetal removals, while the phase of plein debitage 
corresponds to the detachment of two oval medium-sized flakes. The preferential Levallois core has a mostly natural striking platform with two removals perpendicular to the intersection plane of the two core surfaces, preparing the surface in correspondence of the impact point of the predetermined flake. On the knapping surface, one of the lateral convexities is natural, while three centripetal removals prepare the distal and the other lateral convexity.

Level 14 is the S.U. where Levallois technology is better attested and it is applied on all the raw materials, even if the reduction sequences are complete just for vein quartz and grey/black flint (Tab. 9). The Levallois method aims to the production of oval/quadrangular flakes, usually short and large, even if some elongated flakes are sporadically attested in the assemblage. Fluvial pebbles with natural suitable morphologies and convexities are chosen as cores. All the Levallois cores show just one phase of exploitation, after which they are discarded. The core surfaces are barely prepared, being the striking platforms completely natural or shaped through just a few detachments according to a centripetal direction. In the preferential modality, a single removal, perpendicular to the plan of intersection of the two core surfaces, prepares the portion of the core to be hit through hard hammer percussion for the detachment of the preferential flake. On the knapping surface, two or three removals, mainly centripetal, are needed to set the distal and the lateral convexities. Just one Levallois vein quartz core is referred to the recurrent centripetal modality. In this case too, the convexities are naturally present on the core, but the striking platform surface is prepared through chordal and centripetal removals in correspondence of the impact points of the predetermined flakes. Four removals are present on the knapping surface, corresponding to one phase of exploitation, after which the core has been abandoned. The research for predetermined products is inferable from the use of both centripetal and chordal removals for the maintenance of suitable convexities even for a so short production phase. No Levallois cores are attested for spongolite, while a recurrent centripetal core is present in the grey/black flint assemblage (Fig. 6). No significative differences are evident between this Levallois reduction sequence and those observed on vein quartz: the striking platform surface is natural, with not any removal for the preparation of its convexity, thus confirming the choice of blanks with natural suitable convexities even in case of better-quality raw materials. The main difference is the presence of more than one phase of exploitation on this flint core, that has been completely exhausted before being discarded. The wanted products share the same morphological and dimensional characteristics observed on vein quartz cores.

The characteristics of Levallois reduction sequences present in level 15 are consistent with those of the previous layers and just on vein quartz they are complete. Two vein quartz cores are present in in the assemblage (Tab. 10), belonging to the preferential and the recurrent centripetal modality respectively. The preferential core is realized on a pebble and has a neocortical striking platform with one detachment in correspondence of the impact point of the preferential flake; it was abandoned after only one exploitation phase, with nine centripetal and sometimes debordant removals that prepare the lateral and distal convexities of the knapping surface. The recurrent centripetal Levallois core show two exploitation phases: first, the convexity of the striking platform is prepared through three centripetal removals and the knapping surface is exploited to produce four predetermined flakes; the second exploitation phase consists in the exploitation of a third surface through two removals which debitage direction is perpendicular to the intersection plane between the two core surfaces. The wanted products are oval and quadrangular medium-sized flakes, sometimes elongated, which dimensional characteristics are strongly influenced by those of the blanks chosen as cores.

Concerning level 103, even in this case Levallois reduction sequences are complete just for vein quartz. This method is here represented by a total of five flakes and by one core (Tab. 11), so just a few technological considerations can be made about how it was performed. All the artefacts are referred to the recurrent centripetal modality and the characteristics of the butts, together with those showed by the only one core present in the assemblage, suggest that flat or neocortical surfaces 
were chosen as striking platforms without shaping of the core convexities. The core show one phase of exploitation through five centripetal removals, after which it was discarded.

Even if quite limited in number, Levallois products and cores allow to make some observations concerning the general organization of the reduction sequences, starting from the choice of the blanks to be exploited until the adaptation of the technological criteria defining these two methods (Boëda, 1994, 1993; Peresani, 2003) to the raw materials constraints.

The débitage direction is always parallel to the intersection plane between the core surfaces and the characteristics of the cores of the Ciota Ciara cave indicate that Levallois reduction sequences were performed only on pebbles with natural suitable convexities, thus leading to a great influence of the core morphology on that of the desired products. All the vein quartz Levallois cores has been discarded after one phase of exploitation.

Concerning Levallois products, the dimensional analysis (Fig. 6) gives results consistent with the observations made on the cores regarding the general morphology of the predetermined products: oval, medium-sized flakes, sometimes elongated. Just concerning level 103 it was not possible to complete a dimensional analysis because most of the Levallois products is fragmented. In level 13, two findings attest the production of quartz points: a Mousterian point (Fig. 6) and a distal fragment of a Levallois point. The characteristics of the butts confirms the choice of natural or flat surfaces (i.e. prepared through a single removal) as striking platforms. A slight difference can be highlighted between vein quartz and the other raw materials: on vein quartz, the choice of neocortical surfaces is preferred, while prepared butts, dihedral or faceted, are attested just on radiolarite and grey flint.

\subsubsection{Discoid reduction strategies}

As for Levallois technology, discoid reduction strategies have been identified in all the archaeological layers of the Ciota Ciara cave, in two modalities: bifacial and unifacial (Fig. 7). In level 13, discoid exploitation is attested and presents complete reduction strategies only concerning vein quartz and spongolite (Tab. 8). In both cases, cores are represented by centimetric blanks $(\leq 10$ $\mathrm{cm}$ length) with natural suitable convexities. They area exploited with few centripetal removals with débitage direction secant to the plane of intersection of the two core surfaces. Usually they present just one phase of exploitation, that is enough to exhaust the core.

Concerning S.U. 14, the discoid method is applied on all the raw materials (Tab. 9), even though just for vein quartz, spongolite and grey flint they are complete, given the presence of both cores and products. On vein quartz, both the unifacial and bifacial modalities are present with short reduction sequences aimed to produce short and large flakes, often quadrangular, and characterized by a thickness generally higher than for products issued from Levallois reduction sequences (Peresani, 2003; Picin and Vaquero, 2016). The cores are discarded before their complete exhaustion and after just one or two exploitation phases. Natural surfaces are often still present on the cores and when an unifacial exploitation is employed, the striking platform surface is neocortical or represented by a natural fracture plane. The cores are chosen among blanks with suitable natural convexities and their morphology strongly influences the dimensions of the obtained products. Some discoid cores are realized on big flakes, probably issued from an opportunistic exploitation. The negatives of the removals visible on the cores mostly follows a centripetal direction, while chordal detachments are visible just when on the core are present two exploitation phases: the maintenance of the core convexities took place just in the longest discoid reduction sequences, while when only one exploitation phase is completed, the removals follow exclusively a centripetal direction. Concerning core selection, modalities of exploitation and wanted products, no differences have been observed between the different raw materials. On spongolite too, discoid reduction sequences are short and applied just on blanks with natural suitable convexities. The cores are exploited through a few centripetal detachments.

Discoid reduction sequences are well represented in level 15 and cores are present both for vein quartz and spongolite (Tab. 10). No significative differences are evident comparing vein quartz and spongolite discoid cores: for both the raw materials cores are chosen among centimetric pebbles or 
blocks collected in secondary deposits presenting suitable convexities. The exploitation starts directly from the natural surfaces of the cores and after the removal of a few discoid flakes, the cores are discarded even if not exhausted. For the unifacial exploitation, the striking platform is always neocortical or represented by a natural flat surface. Due to the shortness of the production phases, no great attention is paid to the management of the cores convexities that usually are exploited only through centripetal detachments.

In level 103, discoid reduction sequences are attested by a quite low number of cores and products (Tab. 11) making difficult to achieve reliable data on how the different raw materials were exploited. The three cores found attest that both the unifacial and the bifacial modalities have been employed. The two discoid quartz cores show just a few centripetal detachments, with a débitage direction secant to the intersection plane between the core surfaces. The discoid spongolite core shows only two centripetal detachments on one of the surfaces, while the other is natural. It attests, also for this raw material, the use of blanks with suitable morphologies to avoid the shaping of the core.

The débitage direction is always markedly secant to the intersection plane between the two core surfaces, thus showing a different volumetric conception of the core compared to those of the Levallois reduction sequences, characterized by a parallel débitage direction. The products obtained are small flakes sometimes with a lateral plunging. The butts, mainly flat and natural for all the raw materials, confirm the observations made on the cores regarding the preferential choice of flat surfaces as striking platforms and represented by neocortical surfaces or fracture planes.

\subsubsection{Use-wear analysis}

Concerning the experimental collection, the characteristics of the use-wear traces identified on spongolite, flint and vein quartz (Fig. 8) artefact are comparable to those present in literature (e.g. Hayden, 1979; Lemorini et al., 2006; Lemorini and Cristiani, 2002; Solodenko et al., 2015; Visentin et al., 2016).

In level 14, almost half of the selected sample (41\% - 28 artefacts, 30 zones of use) shows diagnostic traces of use. Quartz and flint products were used to perform the same kind of activities with similar percentage. Moreover, a fraction of the artefacts could have been so lightly used that no visible traces developed. Although probably under-represented, the total number of used artefacts of level 14 allows a good interpretation of the use-wear patterns.

Traces of use have been identified on 19 vein quartz (Fig. 9) and 9 flint flakes (Fig. 10). Concerning quartz, 5 of the artefacts with traces are Levallois flakes ( 3 preferential and 2 recurrent centripetal flakes), 1 is a discoid flake and 13 are opportunistic/S.S.D.A. flakes. Among them, 1 opportunistic flake has 2 zones of use (Z.U.) referable to two different types of traces: transversal work on bone and longitudinal work on fresh hide (Tab. 12). Concerning flint, use-wear traces have been identified on 3 Levallois flakes (1 preferential and 2 recurrent centripetal flakes), 2 discoid flakes and 4 opportunistic S.S.D.A. flakes (Tab. 13), of which one has 2 Z.U.

The use wear analysis led to the identification of different activities carried out in the site that can be divided in two main groups: animal carcass processing (that include the categories: butchering, fresh and dry hide working) and vegetal material processing.

Animal carcass processing activities were more often performed including different phases of carcass exploitation, from butchering to bone and soft animal tissue working. In this group are also included artefacts with traces of contact with fleshy tissues in association with traces of contact with bone or fresh hide ( $22 \%$ - 7 tools) that are referred to activities such as skinning, evisceration, disarticulation and de-fleshing of carcasses (Lemorini et al., 2006). The artefacts with traces of fresh and dry hide working (5) suggest the presence of some type of tanning activity performed in the site (Anderson-Gerfaud, 1990; Beyries, 1987; Lemorini, 2000; Palmqvist et al., 2005). Bone working ( $19 \%$ - 6 tools), linked mainly to a transversal action ( 5 tools) can be referred to the periosteum removal, necessary for marrow extraction (Grayson, 1984). The artefacts with traces of contact with fleshy tissues (2) are probably linked to filleting activities. 
Vegetal material processing was performed less frequently and in this group are included wood working and non-woody plant working. Woodworking traces can be interpreted as a result of the manufacture of spears or of other utilitarian wood objects (Rots and Hardy, 2015). However, part of these traces and actions can also be associated with herbaceous plants processing, thus suggesting that the Ciota Ciara inhabitants may have gathered such materials in addition to animal carcasses. If we look just at the formal tools, we observe that the activities carried out are the same of those performed with unretouched flakes (Tab. 14). All the formal tools, made in quartz and in local flint, were discarded before exhaustion, suggesting only brief use, probably related to a single activity (Lemorini et al., 2006). On the contrary, the tools made in allochthonous flint have more than one phase of reshaping and were probably used for several activities and/or for long time during the same activity. This behaviour can be due to the general low efficiency of the cutting edges made in quartz and local flint: as observed during the experimentation, spongolite and vein quartz tends to be less efficient than flint even if the time of use and the activity performed are the same. This data is confirmed by the relatively high presence of traces on tools made in allochthonous flint despite their scarce numeric presence in the lithic assemblage (Berruti and Arzarello, 2012; Daffara et al., 2019).

\section{Discussion}

\subsection{Technological study}

The studies on the lithic assemblage of the Ciota Ciara cave allow to achieve significative data about the technological behaviour of the prehistoric human groups frequenting the region. The technological study underlines an articulated technological behaviour that includes a great knowledge of the natural resources available, both in the immediate surroundings of the site and on a wider scale (Daffara et al., 2019), and of the mechanical properties of the different rocks involved in the production of tools. Looking at the general composition of the lithic assemblage and to the proportion of the different technological categories according to the raw materials employed (Tab. $8,9,10,11)$, it is evident that the general behaviour did not change significantly during the different phases of frequentation of the cave. All along the sequence the same reduction sequences are attested, in similar proportions, with the preferential use of pebbles and slabs as cores and very limited presence of debitage on flake (i.e. Kombewa s.l.). In all the archaeological layers, knapping activities took place in the site concerning the most represented raw materials (vein quartz, spongolite and grey flint) while secondary local rocks like opal and jasper are probably knapped close to the area where they were collected. In a diachronic perspective, a change is visible between level 14 and 15 in the proportion of vein quartz and spongolite, that here represents $50,6 \%$ and $44,4 \%$ of the lithic assemblage respectively (Tab. 4). According to palaeontological (Berto et al. 2016; Cavicchi, 2018) and geoarchaeological data (Angelucci at al., 2018), the deposition of level 15 corresponds to climatic changes leading to cold and arid conditions. Technological data suggest that in level 15 the site was occupied for brief periods, probably corresponding to temporary stops along hunting paths. In this level we observe a more marked fragmentation of the reduction sequences and an increasing in the use of spongolite: the changes in the climatic conditions could have modified the accessibility of the local raw materials outcrops and secondary deposits; on the other hand, changes in site use could have led to different choices in the raw materials supply strategies.

Further slight differences among the archaeological levels are visible in the presence/absence of some secondary rocks and in the completeness or fragmentation of some reduction sequences of local flint and spongolite; given the low number of spongolite and flint Levallois flakes and cores, it is realistic to suppose that this method has been barely employed on these rocks, but different hypothesis can also be done: 1. Levallois cores have not been abandoned but further exploited through opportunistic methods and have not been recognized during the technological analysis; 2 . the Levallois flakes present in the spongolite and flint assemblages suggests that only blanks with 
homogeneous texture and without inner flaws or impurities were selected for this kind of exploitation and it can be supposed that they were exploited directly where they were collected. Considering the characteristics of the opportunistic cores found, we are in favour of the second hypothesis, both for the modalities of exploitation of the opportunistic cores and for their textural features.

In general, the characteristics of the lithic assemblages belonging to each archaeological layer seems to depend only on the intensity of the human frequentation of the site, probably linked to changing in the climatic environment (Angelucci et al., 2018; Arzarello et al., 2012; Berto et al., 2016; Daffara et al., 2014).

Discoid and Levallois methods are well attested in the site and give the chance to make some considerations about the adaptation of their technological criteria to the characteristics of the raw materials, particularly concerning vein quartz. A first adaptation to vein quartz is visible in the general shortness of the reduction sequences: both discoid and Levallois exploitations start from the natural surfaces of the cores (neocortical surfaces or natural fracture planes) avoiding phases of shaping of the cores. Only for preferential Levallois cores, few removals are realized to prepare the lateral and distal convexities of the knapping surface or to prepare the striking platform in correspondence of the impact point of the preferential flake. After one phase of exploitation the cores are discarded. While for spongolite this is due to the small dimension of the cores, for vein quartz the cores are discarded even when a re-shaping of the core would have permitted the production of other predetermined products. As demonstrated by experimental studies (de LomberaHermida, 2009; Tallavaara et al., 2010) the most the exploitation proceeds, the most the results of the knapping activity are unpredictable due to the formation of further inner fracture planes in vein quartz cores. A further adaptation to vein quartz is the frequent use of neocortical surfaces as striking platforms, that contributes in reducing the occurrence of knapping accidents and fractures (Mourre, 1996, 1994). The development of discoid and recurrent centripetal production phases suggests that the intention to discard the core after the detachment of a reduced number of blanks was a usual technical behaviour at the Ciota Ciara cave. In levels 14 and 15, where these reduction sequences are most developed, it is not visible an attention for the management of the core convexities: the removals are rarely debordant or directed toward a chordal direction, as usually observed on cores with several production phases.

The technological features of Levallois and discoid products and cores realized on better quality raw materials (i.e. radiolarite and local flint), like the presence of prepared butts, attests that on these rocks the reduction sequences should have been more complex and longer than on vein quartz and spongolite, thus confirming that the shortness of vein quartz and spongolite reduction sequences was an intentional choice and not caused by a technological ineptitude (Lo Porto, 1957).

The clear predominance of opportunistic knapping methods in the considered assemblage can be interpreted as a further adaptation to raw materials constraints: being the employment of Levallois and discoid methods strictly subject to the availability of natural blanks with suitable morphologies, the easiest way to obtain lithic tools is to exploit all the type of natural blanks available through simple reduction strategies (Matilla, 2010; Moncel et al., 2014; Moncel and Lhomme, 2007; Ortega and Maroto, 2001; Santagata et al., 2017; Thiébaut et al., 2012).

A further consideration must be made concerning local flint, the best quality raw material present in the Monte Fenera area. Its limited use in all the archaeological levels is ascribable to the limited extension of the outcrops (Daffara et al., 2019) where, on the other hand, it appears to be available in blanks with considerable dimensions. For this reason, even if the number of cores is scarce, the reduction sequences linked to this raw material can be considered as complete, since it is likely to hypothesize that a considerable number of products could have been obtained from the exploitation of a reduced number of blanks.

The technological analysis of the lithic assemblage of the Ciota Ciara cave allow to make some considerations about the general technological behavior of the human groups frequenting the cave during Middle Palaeolithic. The availability and quality of the raw materials in the surroundings of 
the site, plays an important role in the strategies of tools production adopted and strongly affects the characteristics of the final products (Andrefsky Jr., 1994). In the considered site, most of the lithic tools are produced and discarded in the site, suggesting that the local raw materials were exploited to satisfy immediate needs with a low technological investment (exploitation of natural surfaces, predominance of opportunistic reduction strategies, scarce presence of retouched tools, minimal presence of phases of core configuration). Some of the elements defining curated technological behaviors, like the production of tools as anticipation of future needs and tools maintenance (Bamforth, 1986; Binford, 1979; Torrence, 1983) are identified concerning allochthonous raw materials, i.e. radiolarite and rhyolite: at the Ciota Ciara cave are introduced radiolarite and rhyolite finished tools that are used and reshaped several times before being discarded, as attested by the presence of some retouch flakes in the lithic assemblage (Tabs 8, 9, 10, 11). According to Kelly (1988), the factor influencing this kind of behavior is mobility: during seasonal movements, multifunctional tools were transported to face different kind of issues related to the acquisition of resources. Nevertheless, they represent a minority in the considered lithic assemblage, that can be described as mainly characterized by an expedient technological behavior (Andrefsky Jr., 1994; Binford, 1979; Vaquero and Romagnoli, 2017).

In conclusion, the technological analysis suggest that the Ciota Ciara cave was mainly used for short-term occupations, linked to the exploitation of local resources. Level 13 provides data for the interpretation of the site as a base camp: local raw materials were introduced in the site and exploited to produce tools that were used for activities probably linked to the maintenance of hunting implements and to carcass processing (Daffara et al., 2014). Similarly, the characteristics of level 15 lithic assemblage suggest short-term human frequentations; on the other hand, the significative presence of allochthonous raw materials, let us suppose that the human occupation of this level was characterized by a more intense regional mobility. Only level 14 seems to provide data for longer staying but always characterized by seasonal movements. This data agrees with the results of zooarchaeological and paleontological analysis (Arzarello et al., 2012; Berto et al., 2016; Buccheri et al., 2016; Cavicchi, 2018).

\subsection{Use-wear analysis}

The total number of artefacts with use-wear traces present in level 14 allows a reliable interpretation of the use-wear patterns. Animal carcasses processing were often performed, including different phases of carcass exploitation: butchering, work of fresh and dry hide, bone and soft animal tissues working. In the group of artefacts classified as butchering tools (7) are placed those with traces of contact with fleshy tissues in association with traces of contact with bone and fresh hide: they are referred to activities like skinning, evisceration, disarticulation and de-fleshing of carcasses (Lemorini et al., 2006). The tools with traces of fresh and dry hide work (4), suggest the presence of some type of tanning activity performed in the site, i.e. long lasting processes (Anderson-Gerfaud, 1990; Beyries, 1987; Lemorini et al., 2006; Palmqvist et al., 2005). The tools with traces of contact with fleshy tissues (2) are probably linked to filleting activities. Bone working (6 tools), mainly linked to a transversal action ( 5 tools) can be related to the periosteum removal, necessary during marrow extraction (Grayson, 1984). This data is consistent with the archaeozoological results that highlight the presence of several bones with clear traces of scraping activities (Buccheri et al., 2016). The archeozoological study completed on the faunal remains of S.U. 14 also allowed the identification of three different activities: evisceration, filleting and skinning (Buccheri et al., 2016). Skinning is attested by the presence of cuts-marks on a skull and a scapholunar of Ursus spelaeus. Some faunal remains present also traces of flesh extraction, as suggested by one scraping trace on the ventral side of a thoracic vertebra (vertebral body) and by various scarification traces on two humeri and two tibias placed near the insertions of the muscle masses. Finally, the presence of cutmarks on the atlas dorsal face can be related to disarticulation or filleting activities (Buccheri et al., 2016). These data are consistent with the traces found by the use-wear analysis completed. 
Less frequent is the processing of woody and non-woody plants and traces linked to these kind of activities can be referred to the manufacture of spears or of other utilitarian wood objects (Hardy, 2018; Rots and Hardy, 2015). However, part of these traces and actions can also be associated with herbaceous plants processing, thus suggesting that the Ciota Ciara cave inhabitants may have gathered such materials in addition to animal carcasses as completion of the diet and/or as medicine (Hardy, 2018).

In S.U. 14, the development of various and well documented activities is suggested by the use-wear study carried out together with the results of the archeozoological analysis (Buccheri et al. 2016), thus suggesting a medium-term occupation of the cave (Stiner, 2013). This hypothesis is also supported by the comparison between level 14 and the other archaeological layers of the Ciota Ciara cave. In level 14 we have an increasing in the number of lithic artefacts (Arzarello et al. 2012; Daffara et al. 2014); an increasing in the number of imported lithic artefacts (Daffara 2017); the presence of a fireplace (Angelucci et al. 2018); an increasing in the number of herbivorous remains (Berto et al., 2016; Cavicchi, 2018); the presence of faunal remains with cut-marks (Buccheri et al. 2016). Then, it is reliable to suppose that, during the deposition of this level, the human occupations were characterized by a strong exploitation of animal resources, with long lasting processes, as hide treatments, combined with the exploitation of vegetal resources (Hardy, 2018).

If compared with the results obtained from the use-wear analysis of level 13, interpreted as a result of short-term residential occupation characterized by complete reduction sequences mainly linked to the transformation of materials and to the acquisition of primary resources (Arzarello et al., 2012), the frequentation of the S.U. 14 seems to be the result of medium-term occupations characterized by a more complex set of activities. The results of the use-wear analysis of the lithic assemblage of level 13 show that during this phase of human frequentation of the site, long-lasting activities like hide processing were not performed. The lithic artefacts have mainly traces referred to the processing of hard and medium hard materials (i.e. wood); these activities could be linked to the production and maintenance of spears or of other objects of daily use (Hardy, 2018). The low variety of activities performed and the absence of long-lasting processes, let us suppose that during the deposition of level 13, the Ciota Ciara cave was inhabited for short time periods, probably as a base camp for hunting activities (Daffara et al., 2014)

It is interesting to note that, as already underlined in other studies (Claud, 2012; Hardy, 2004; Lazuén and González-Urquijo, 2015; Lemorini et al., 2016, 2006, 2003; Zupancich et al., 2016), in the considered lithic assemblage there does not seem to be any clear specific relationship between the method used to realize the tools and the activity performed. Even between discoid and Levallois products there are not clear differences in terms of type of actions and activities carried out.

\subsection{Where is predetermination?}

Together with vein quartz, that is the predominant raw material in all the levels, spongolite is the most exploited rock. The results obtained by the technological analysis of their reduction sequences, let us make reliable considerations about the technological behavior of the Middle Palaeolithic human groups that inhabited the Ciota Ciara cave. Vein quartz and spongolite are introduced as natural blanks and knapped in the site according to opportunistic/S.S.D.A. (Forestier, 1993), discoid (Boëda, 1993; Peresani, 2003) and Levallois (Boëda, 1994) exploitation strategies. Looking at the characteristics of these raw materials, the preponderance of vein quartz in the assemblage cannot be explained only through its greater availability in the local environment (Daffara et al., 2019) but its characteristics as well as the dimensions and morphology of the blanks available should be taken into account. According to the features of the natural surfaces visible in the archaeological record, both were collected in secondary deposits; the surveys carried out (Berruto, 2016, 2011) show that vein quartz is available in different morphologies, i.e. rounded pebbles and polygonal blocks of different size, and spongolite is mostly available as centimetric slabs ( $\leq 10 \mathrm{~cm}$ length), while polygonal blocks are mostly of reduced dimensions. Moreover, spongolite always presents several 
inner cleavages that strongly condition its response to knapping. Another significative aspect was observed during the experimental work completed: given the same time of use and the same material worked, spongolite seems to be less efficient not only than flint but also than vein quartz. Even if a specific experimental work should be completed to prove this hypothesis, it could explain why, in the local environment, vein quartz was more attractive than spongolite for knapping activities.

The strong relation between the initial morphology of the cores and the knapping method is evident all along the sequence. While the opportunistic/S.S.D.A. method is applied on almost all the types of blanks (rounded pebbles, polygonal blocks and slabs), discoid and Levallois methods are employed exclusively on cores with suitable morphologies, vein quartz rounded pebbles and small spongolite polygonal blocks. This implies that the final dimensions of Levallois and discoid products is strongly influenced by those of the natural blanks selected as cores. Well, if the production of Levallois flakes is so strongly affected by the initial morphology of the cores, where is predetermination? i.e. the exploitation of rounded pebbles through reduction sequences that accomplish the volumetric criteria proper of the Levallois method was aimed to the production of predetermined tools or was it just the easiest way to exploit that volume? It is not easy to answer this question, since several of the Levallois cores present in the considered lithic assemblages show that the phase of plein debitage starts directly from the natural surfaces of the pebble; on the other hand, especially concerning Levallois preferential cores, the presence of centripetal removals on the knapping surface arranging the natural lateral and distal convexities before the detachment of an invasive flake, suggest that the choice of pebbles with that characteristics was intentionally aimed to the production of Levallois flakes, which morphologies were clearly predetermined. Moreover, flaking is always organized around a plane of intersection, with asymmetrical and hierarchized surfaces, thus showing a control of the geometry and volume of the core (Moncel et al., 2020). Concerning discoid technology, the concept of predetermination has been widely debated between scholars that recognize to this knapping method a high degree of predetermination (Boëda, 1993; Delpiano et al., 2018; Locht and Swinnen, 1994; Mourre, 2003) and those considering discoid as an expedient method used to reduce efficiently the core volume through series of recurrent centripetal removals (Vaquero et al., 2012; Wiśniewski, 2014). The great variability recognized in the discoid method concerning core morphologies and modalities of core exploitation, made this method more flexible than Levallois, thus generating a huge quantity of variables compared to its classical definition (Boëda, 1993; Peresani, 2003). At the Ciota Ciara cave, discoid knapping strategies are applied only on natural blanks with suitable morphologies and start directly from natural surfaces. Dimensions and morphology of the products are strongly influenced by those of the cores, leading to the hypothesis that the discoid method could here represent just an expedient core exploitation (Picin et al., 2014; Picin and Vaquero, 2016; Vaquero and Carbonell, 2003).

However, the discoid method is applied on natural blanks that have the same morphological characteristics of those exploited through Levallois methods. The choice of exploiting that volume according to a discoid conception can then be interpreted as intentional, with knapping sequences aimed to the production of flakes with morphological characteristics different from those issued from Levallois reduction strategies.

Even if the technological behavior observed at the Ciota Ciara cave can be defined as expedient (Andrefsky Jr., 1994; Bamforth, 1986; Kelly, 1988; Vaquero and Romagnoli, 2017), predetermination is evident in the adaptation of Levallois and discoid concepts to the natural convexities present on the core. The same natural convexities can be exploited to obtain Levallois or discoid products, highlighting the intentional choice made by the knappers. The volumes of the rounded pebbles collected are exploited according to plans secant or parallel to the plan of intersection between the core surfaces, thus determining the main difference between a Levallois and a discoid exploitation strategy in the considered assemblage.

\section{Conclusions}


The study of the lithic assemblage of the Ciota Ciara cave clearly shows that the general technological behaviour does not change all along the sequence and can be defined as expedient. In all the archaeological layers there is a clear predominance of local rocks (particularly vein quartz) and a marginal presence of allochthonous raw materials. Opportunistic reduction strategies are the most represented in all the phases of human frequentation of the site even if Levallois and discoid methods are well attested. The results obtained show that the quality of the raw materials strongly affected the development of the reduction sequences. On the other hand, at the Ciota Ciara cave we do not observe any correlation between Levallois/good quality raw materials and discoid/low quality raw materials. In our opinion, generalize such kind of correlation could be misleading in the analysis and interpretation of a lithic industry.

In the considered assemblage all the raw materials have been exploited in the same way, with specific adaptation strategies to the raw materials constraints. Concerning vein quartz and spongolite, the production of lithic tools is characterized, for all the knapping methods, by a low technological investment; rocks with better response to knapping, like radiolarite and local flint, are exploited in a more curated way, as testified by the presence of prepared butts and by cores with reshaping of the knapping surfaces. This difference highlights that the roughness of vein quartz and spongolite reduction sequences is due to adaptations to the raw materials properties.

The use-wear analysis highlights that there was not any difference in the use of the lithic artefacts according to the method they were issued from. This data suggests that the aim of the knappers was mainly to obtain cutting edges to satisfy their needs in the easiest and fastest way, exploiting the volumes of the natural blanks through the most appropriate method.

In conclusion, it is undeniable that the general technological behaviour can be interpreted as expedient; however, it is evident that the Middle Palaeolithic hunter gatherers of the Ciota Ciara cave adapted technological concepts proper of their background to the resources available, showing great technological skills and the capability to practice flexible adaptation strategies.

\section{Acknowledgements}

The authors would like to dedicate the present work to the loving memory of Teresio Baroli. This work has been possible thanks to the International Doctorate in Quaternary and Prehistory (IDQP) programme. We also would like to thank the Borgosesia municipality, the members of the former G.A.S.B. (Gruppo Archeologico Speleologico di Borgosesia) and all the students and researchers that participate in the archaeological investigations of the Ciota Ciara cave.

\section{References}

Anderson-Gerfaud, P., 1990. Aspects of Behavior in the Middle Paleolithic: Functional Analysis of Stone Tools from Southwest France, in: Mellars, P. (Ed.), The Emergence of Modern Humans: An Archaeological Perspective. Edinburgh University Press, Edimburgh, pp. 389-418.

Andrefsky Jr., W., 2009. The analysis of stone tool procurement, production, and maintenance. J. Archaeol. Res. 17, 65-103.

Andrefsky Jr., W., 1994. Raw-Material availability and the organization of technology. Am. Antiq. $59,21-34$.

Angelucci, D.E., Arnaud, J., Berruti, G.L.F., Berruto, G., Berté, D., Buccheri, F., Casini, A.I., Daffara, S., Luzi, E., Lopez Garcia, J.M., Peretto, C., Zambaldi, M., 2015. Borgosesia , Monte Fenera . L' occupazione dati dalla campagna di scavo 2014. QUASAP 400-402.

Angelucci, D.E., Zambaldi, M., Tessari, U., Vaccaro, C., Arnaud, J., Berruti, G.L.F., Daffara, S., Arzarello, M., 2018. New insights on Monte Fenera Palaeolithic (Italy): Geoarchaeology of the Ciota Ciara cave. Geoarchaeology 34, 413-429.

Arnaud, J., Arzarello, M., Berruti, G., Berruto, G., Berté, D., Berto, C., Buccheri, F., Iliana, A., Daffara, S., Luzi, E., Garcia, L., Manuel, J., Peretto, C., 2013. Borgosesia, Monte Fenera. Grotta della Ciota Ciara: Nuovi dati sull'occupazione musteriana. QUASAP 148-150.

Arzarello, M, Daffara, S., Berruti, G., Berruto, G., Berté, D., Berto, C., Gambari, F.M., Peretto, C., 
2012. The Mousterian Settlement in the Ciota Ciara Cave: the oldest evidence of Homo Neanderthalensis in Piedmont (Northern Italy). J. Bio. Res. LXXXV, 71-75.

Arzarello, M., Daffara, S., Berruti, G., Berruto, G., Berté, D., Berto, C., Gambari, F.M., Peretto, C., 2012b. The mousterian settlement in the ciota ciara cave: The oldest evidence of homo neanderthalensis in piedmont (Northern Italy). J. Biol. Res. https://doi.org/10.4081/jbr.2012.4068

Bamforth, D.B., 1986. Technological efficiency and tool curation. Am. Antiq. 51, 38-50.

Berruti, G.L.F., Arzarello, M., 2012. L'analisi tracceologica per la ricostuzione delle attività nella preistoria: l'esempio della Grotta della Ciota Ciara (Borgosesia, VC). Ann. dell'Università di Ferrara, Mus.Sci. Nat. 8, 117-124. https://doi.org/ISSN 1824-2707

Berruto, G., 2016. Approvvigionamento in materie prime litiche e paleo- ambiente: comportamento economico dei neandertaliani della grotta della Ciota Ciara (Borgosesia, VC). Università degli studi di Genova. Scuola di specializzazione in Beni Archeologici.

Berruto, G., 2011. Comportamento economico dei neandertaliani della grotta della Ciota Ciara (Borgosesia, VC): analisi della provenienza delle materie prime. University of Ferrara.

Berto, C., Bertè, D., Luzi, E., Lopez Garcia, J.M., Pereswiet-Soltan, A., Arzarello, M., 2016. Small and large mammals from Ciota Ciara cave (Borgosesia, Vercelli, Italy): an Isotope stage 5 assemblage. Comptes Rendus - Palevol 15, 669-680.

Beyries, S., 1987. Variabilité de l'industrie lithique au Moustérien: approche fonctionnelle sur quelques gisements français. British Archaeological Reports International Series 328, Oxford.

Binford, L.R., 1979. Organization and formation processes: looking at curated technologies. J. Anthropol. Res. 35, 251-273.

Boëda, E., 1994. Le concept Levallois: variabilité des méthodes. Archéo éditions.

Boëda, E., 1993. Le débitage discoïde et le débitage Levallois récurrent centripète. Bull. la Société préhistorique française 90, 392-404.

Boëda, E., Geneste, J.-M., Meignen, L., 1990. Identification de chaînes opératoires lithiques du Paléolithique ancien et moyen. Paléo 2, 43-80. https://doi.org/10.3406/pal.1990.988

Bordes, F., 1961. Typologie du Paléololithique ancien et moyen. 2 Vols. Mémoires de l'institut Préhisorique de 1'Université de Boreaux 1.

Brecciaroli Taborelli, L., 1995. Un insediamento temporaneo della tarda antichità nella grotta "Ciota Ciara." Quad. della Soprintend. Archeol. del Piemonte 13, 73-135.

Buccheri, F., 2014. Analisi tafonomica dei resti paleontologici dell ' US 14 della grotta della Ciota Ciara (Paleolitico Medio) Borgosesia, VC, Italia. Università degli studi di Ferrara.

Buccheri, F., Bertè, D.F., Luigi, G., Berruti, F., Cáceres, I., Volpe, L., Arzarello, M., 2016. Taphonomic Analysis on Fossil Remains From the Ciota Ciara Cave (Piedmont, Italy) and New Evidence of Cave Bear and Wolf Exploitation With Simple Quartz Flakes By Neanderthal. Riv. Ital. di Paleontol. e Strat. 122, 41-54. https://doi.org/10.13130/20394942/7674

Busa, F., Gallo, L.M., Dellarole, E., 2005. L'attività di ricerca nelle grotte del Monte Fenera, in: Fantoni, R., Cerri, R., Dellarole, E. (Eds.), D’acqua e Di Pietra. Il Monte Fenera e Le Sue Collezioni Museali. Associazione culturale ZEISCIU Centro Studi, Alagna Valsesia, pp. 218223.

Cavicchi, R., 2018. Biocronologia, paleoecologia e paleoambiente della grotta Ciota Ciara (Borgosesia, Vercelli, Piemonte): nuovi dati dalla sequenza a grandi mammiferi. Università degli studi di Ferrara.

Chazan, M., 1997. Redefining Levallois. J. Hum. Evol. 33, 719-735. https://doi.org/10.1006/jhev.2002.0573

Claud, E., 2012. Étude tracéologique de l'outillage moustérien de type Quina du bonebed de ChezPinaud à Jonzac (Charente-Maritime). Nouveaux éléments en faveur d'un site de boucherie et de traitement des peaux. Gallia 54, 3-32.

Clemente-Conte, I., Gibaja Bao, J.F., 2009. Formation of use-wear traces in non-flint rocks: the 
case of quartzite and rhyolite - differences and similarities, in: Sternke, F., Eigeland, L. (Eds.), Non-Flint Raw Material Use in Prehistory Old Prejudices and New Directions . BAR International Series, pp. 93-98.

Colonge, D., Mourre, V., 2006. Quartzite et quartzites: aspects pétrographiques, économiques et technologiques des matériaux majoritaires du Paléolithique ancien et moyen du sud-ouest de la France, in: Grimaldi, S., Cura, S. (Eds.), Technological Analysis on Quartzite Exploitation. Proceedings of the XV UISPP World Congress (Lisbon, 4-9 September 2006). BAR International Series 1998. Archaeopress.

Conti, C., 1931. Valsesia Archeologica. Note per una storia dalle sue origini alla caduta dell'Impero Romano.

Cruz, A., Berruti, G.L.F., 2015. Use-Wear Analysis of the Knapped Lithic Grave Goods From Gruta Do Morgado Superior (Tomar, Portugal). Arqueol. Iberoam. 28, 81-94.

Daffara, S., 2017. Non-flint raw materials in the European Middle Palaeolithic: variability of Levallois and discoid knapping methods and study of the supply areas. Doctoral thesis. Universitat Rovira i Virgili - Tarragona.

Daffara, S., Arzarello, M., Berruti, G.L.F., Berruto, G., Bertè, D., Berto, C., Casini, A.I., 2014. The Mousterian lithic assemblage of the Ciota Ciara cave (Piedmont, Northern Italy): exploitation and conditioning of raw materials. J. Lithic Stud. 1, 63-78. https://doi.org/10.2218/jls.v.1102

Daffara, S., Berruti, G.L.F., Berruto, G., Eftekhari, N., Vaccaro, C., Arzarello, M., 2019. Raw materials procurement strategies at the Ciota Ciara cave: New insight on land mobility in north-western Italy during Middle Palaeolithic. J. Archaeol. Sci. Reports 26, 101882. https://doi.org/10.1016/j.jasrep.2019.101882

Daffara, S., Berruti, G.L.F., Caracausi, S., Rodríguez-Álvarez, X.P., Sala-Ramos, R., 2018. The use of "second rate" raw materials during Middle Palaeolithic. Technological and functional analysis of two sites in north-eastern Iberia. Anthropol. 122, 626-653. https://doi.org/10.1016/j.anthro.2018.09.001

de Lombera-Hermida, A., 2009. The Scar Identification of Lithic Quartz Industries, in: Sternke, F., Eigeland, L., Costa, L.J. (Eds.), Non-Flint Raw Material Use in Prehistory . Old Prejudices and New Directions. BAR International Series. Archaeopress, Oxford.

de Lombera-Hermida, A., Rodríguez-Alvarez, X.-P., Peña, L., Sala Ramos, R., Despriée, J., Moncel, M.-H., Gourcimault, G., Voinchet, P., Falguères, C., 2016. The lithic assemblage from Pont-de-Lavaud (Indre, France) and the role of the bipolar-on-anvil technique in the Lower and Early Middle Pleistocene technology. J. Anthropol. Archaeol. 41, 159-184. https://doi.org/10.1016/j.jaa.2015.12.002

de Lombera-Hermida, A., Rodríguez-Rellán, C., 2016. Quartzes matter. Understanding the technological and behavioural complexity in quartz lithic assemblages. Quat. Int. 424, 2-11. https://doi.org/10.1016/j.quaint.2016.11.039

de Lombera-Hermida, A., Rodriguez Rellan, C., 2010. Gestion y estrategias de abastecimiento de las materias primas locales (cuarzo, cuarzita y pizarra) en la prehistoria del NW peninsular, in: Dominguez-Bella, S., Muñoz, J.R., Gutiérrez Lopez, J.M., Pérez Rodriguez, M. (Eds.), Minerales y Rocas En Las Sociedades de La Prehistoria. Encuadernaciones Martinez A.G.S.L. Puerto Real, Cadiz, pp. 49-60.

Delagnes, A., Meignen, L., 2006. Diversity of Lithic Production Systems During the Middle Paleolithic in France. Are there any chronological Trends?, in: Hoverrs, E., Kuhn, S. (Eds.), Transitions before the Transition: Evolution and Stability in the Middle Paleolithic and Middle Stone Age. Springer Science \& Business Media, pp. 85-107. https://doi.org/10.1007/b106329

Delpiano, D., Heasley, K., Peresani, M., 2018. Assessing neanderthal land use and lithic raw material management in discoid technology. J. Anthropol. Sci. 96, 89-110. https://doi.org/10.4436/jass.96006

Di Modica, K., Bonjean, D., 2009. The exploitation of quartzite in Layer 5 (Mousterian) of Scladina cave (Wallonia, Belgium): flexibility and dynamics of concepts of debitage in the Middle 
Palaeolithic, in: Grimaldi, S., Cura, S. (Eds.), Technological Analysis on Quartzite Exploitation. Proceedings of the XV UISPP World Congress (Lisbon, 4-9 September 2006). BAR International Series 1998. Archaeopress, pp. 33-41.

Dibble, H.L., Bar-Yosef, O., 1995. The definition and interpretation of Levallois technology. Prehistory Press, Madison, Wisconsin.

Driscoll, K., 2011. Vein quartz in lithic traditions: An analysis based on experimental archaeology. J. Archaeol. Sci. 38, 734-745. https://doi.org/10.1016/j.jas.2010.10.027

Faivre, J.P., Discamps, E., Gravina, B., Turq, A., Guadelli, J.L., Lenoir, M., 2014. The contribution of lithic production systems to the interpretation of Mousterian industrial variability in southwestern France: The example of Combe-Grenal (Dordogne, France). Quat. Int. 350, 227-240. https://doi.org/10.1016/j.quaint.2014.05.048

Fedele, F., 1972. Aperçu des recherches dans les giesements du Monfenera (Valsesia, Alpes Pennines). Bull. d'etudes Prehist. aplines IV, 5-39 (+ images).

Fedele, F., 1966. La stazione paleolitica del Monfenera in Valsesia. Riv. di Stud. Liguri 1,2, 5-105.

Forestier, H., 1993. Le Clactonien: mise en application d 'une nouvelle méthode de débitage s'inscrivant dans la variabilité des systèmes de production lithique du Paléolithique ancien. Paléo 5, 53-82. https://doi.org/10.3406/pal.1993.1104

Gambari, F.M., 2005. Archeologia del Monte Fenera, in: Fantoni, R., Cerri, R., Dellarole, E. (Eds.), D'acqua e Di Pietra. Il Monte Fenera e Le Sue Collezioni Museali. Associazione culturale ZEISCIU Centro Studi, Alagna Valsesia, pp. 230-233.

Geneste, J.-M., 1991. Systèmes techniques de production lithique: variations techno-économiques dans le processus de réalisation des outillages paléolithiques. Tech. Cult. 17-18, 1-36. https://doi.org/10.4000/tc.5013

Grayson, D.K., 1984. Quantitative Zooarchaeology: Topics in the analysis of archaelogical faunas. Orlando: Academic, Orlando.

Hardy, B.L., 2004. Neanderthal behaviour and stone tool function at the Middle Palaeolithic site of La Quina, France. Antiquity 78, 547-565. https://doi.org/10.1017/S0003598X00113213

Hardy, K., 2018. Plant use in the Lower and Middle Palaeolithic: Food, medicine, and raw materials. Quat. Sci. Rev. https://doi.org/10.1016/j.quascirev.2018.04.028

Hayden, B., 1979. Lithic use-wear analysis. Accademic Press, New York.

Igreja, M., 2009. Use-wear analysis of non-flint stone tools using DIC microscopy and resin casts: a simple and effective technique, in: Recent Functional Studies on Non Flint Stone Tools: Methodological Improvements and Archaeological Inferences. Proceedings of the Workshop. Lisbon, pp. 23-25.

Igreja, M.D.A., 2008. Use-wear analysis of non flint stone tools using DIC microscopy and resin casts: a simple and effective technique, in: Clemente, I., Igreja, M.D.A. (Eds.), Recent Functional Studies on Non Flint Stone Tools: Methodological Improvements and Archaeological Inferences. Proceedings of the Workshop. Lisbon, pp. 23-25.

Inizan, M.-L., Reduron-Ballinger, M., Roche, H., Tixier, J., 1999. Préhistoire de la pierre taillée. Technology and terminology of knapped stones. C.R.E.P., Nanterre.

Jaubert, J., Farizy, C., 1995. Levallois Debitage: Exclusivity, Absence, or Coexistence With Other Operative Schemes (Garonne Basin, SW France), in: Bar-Yosef, O., Dibble, H.L. (Eds.), The Definition and Interpretation of Levallois Technology. Prehistory Press, pp. 227-248. https://doi.org/10.13140/RG.2.1.2330.1206

Keeley, L.H., 1982. Hafting and retooling: effects on the archeological record. Am. Antiq. 47, 798809.

Keeley, L.H., 1980. Experimental Determination of Stone Tool Uses: A Microwear Analysis. University of Chicago Press, Chicago.

Kelly, R.L., 1988. The three sides of a biface. Am. Antiq. 53, 717-734.

Knutsson, H., Knutsson, K., Taipale, N., Tallavaara, M., Darmark, K., 2015. How shattered flakes were used: Micro-wear analysis of quartz flake fragments. J. Archaeol. Sci. Reports 2, $517-$ 
531. https://doi.org/10.1016/j.jasrep.2015.04.008

Knutsson, K., Lindé, K., 1990. No Post-depositional alterations or wear marks on quartz tools, preliminary observations on an experiment with aeolian abrasion, in: Séronie-Vivien, M.R., Lenoir, M. (Eds.), Cahiers Du Quaternaire, Volume 17. Le Silex de Sa Genèse à l'outil. Éditions du C.N.R.S., pp. 607-618.

Kuhn, S.L., 1992. On planning and curated technologies in the Middle Paleolithic. J. Anthropol. Res. 48, 185-214.

Lazuén, T., González-Urquijo, J., 2015. Recycling in the Early Middle Paleolithic: The role of resharpening flakes assessed through techno-functional analysis. Quat. Int. 361, 229-237. https://doi.org/10.1016/j.quaint.2014.04.008

Lemorini, C., 2000. Reconnaître des tactiques d'exploitation du milieu au Paléolithique moyen. British Archaeological Reports 858. Archaeopress, Oxford.

Lemorini, C., Bourguignon, L., Zupancich, A., 2016. A scraper's life history: Morpho-technofunctional and use-wear analysis of Quina and demi-Quina scrapers from Qesem Cave, Israel. Quat. Int. 398, 86-93. https://doi.org/10.1016/j.quaint.2015.05.013

Lemorini, C., Cristiani, E., 2002. Stones, bones and other grave goods in a techno-functional perspective, in: Di Lernia, S., Manzi, G. (Eds.), The Archaeology of Libyan Sahara Volume I Sand, Stones, and Bones. The Archaeology of Death in the Wadi Tanezzuft Valley (5000-2000 BP). Edizioni del Glglio, Roma.

Lemorini, C., Peresani, M., Rossetti, P., Malerba, G., Giacobini, G., 2003. Techno-Morphological and Use-Wear Funtional Analysis: An Integrated Approach to the Study of a Discoid Industry, in: Peresani, M. (Ed.), Discoid Lithic Technology: Advances and Implications. BAR International Series 1120. Archaeopress, pp. 257-275.

Lemorini, C., Plummer, T.W., Braun, D.R., Crittenden, A.N., Ditchfield, P.W., Bishop, L.C., Hertel, F., Oliver, J.S., Marlowe, F.W., Schoeninger, M.J., Potts, R., 2014a. Old stones' song: Use-wear experiments and analysis of the Oldowan quartz and quartzite assemblage from Kanjera South (Kenya). J. Hum. Evol. 72, 10-25. https://doi.org/10.1016/j.jhevol.2014.03.002

Lemorini, C., Stiner, M.C., Gopher, A., Shimelmitz, R., Barkai, R., 2006. Use-wear analysis of an Amudian laminar assemblage from the Acheuleo-Yabrudian of Qesem Cave, Israel. J. Archaeol. Sci. 33, 921-934. https://doi.org/10.1016/j.jas.2005.10.019

Lemorini, C., Venditti, F., Assaf, E., Parush, Y., Barkai, R., Gopher, A., 2014b. The Function of Recycled Lithic Items at Late Lower Paleolithic Qesem Cave, Israel: An Overview of the UseWear Data. Quat. Int. 361, 103-112. https://doi.org/10.1016/j.quaint.2014.07.032

Leroi-Gourhan, A., 1964. Le geste et la parole. Albin Michel, Paris.

Lo Porto, F.G., 1957. Tracce del Musteriano Alpino in una grotta del Monfenera presso Borgosesia. Riv. di Stud. liguri 23, 287-294.

Locht, J.-L., Swinnen, C., 1994. Le debitage discoïde du gisement de Beauvais (Oise): aspects de la chaîne opératoire au travers de quelques remontages. Paléo 6, 89-104.

Manninen, M.A., 2016. The effect of raw material properties on flake and flake-tool dimensions: A comparison between quartz and chert. Quat. Int. 424, 24-31. https://doi.org/10.1016/j.quaint.2015.12.096

Márquez, B., Baquedano, E., Pérez-González, A., Arsuaga, J.L., 2016. Microwear analysis of Mousterian quartz tools from the Navalmaíllo Rock Shelter (Pinilla del Valle, Madrid, Spain). Quat. Int. 424, 84-97. https://doi.org/10.1016/j.quaint.2015.08.052

Matilla, K., 2010. La Chaise-de-Vouthon (Charente), fouilles P.David (1936-1961) et fouilles A. Debénath (1967-1983): un example de débitage bipolaire sur enclume. Paléo. Rev. d'archéologie préhistorique spécial, 63-74.

Moncel, M.-H., Chacón Navarro, M.G., La Porta, A., Fernandes, P., Hardy, B., Gallotti, R., 2014. Fragmented reduction processes: Middle Palaeolithic technical behaviour in the Abri du Maras shelter, southeastern France. Quat. Int. 350, 180-204. https://doi.org/10.1016/j.quaint.2014.05.013 
Moncel, M.-H., Lhomme, G., 2007. Les assemblages lithiques des niveaux du Paléolithique moyen de l'Abri des Pêcheurs (Ardèche, Sud-Est de la France). Des occupations néandertaliennes récurrentes dans un «fossé ». L' Anthropol. 111, 211-253. https://doi.org/10.1016/j.anthro.2007.05.001

Moncel, M.H., Ashton, N., Arzarello, M., Fontana, F., Lamotte, A., Scott, B., Muttillo, B., Berruti, G., Nenzioni, G., Tuffreau, A., Peretto, C., 2020. Early Levallois core technology between Marine Isotope Stage 12 and 9 in Western Europe. J. Hum. Evol. 139. https://doi.org/10.1016/j.jhevol.2019.102735

Moss, E.H., 1983. The Functional analysis of flint implements: Pincevent and Pont d'Ambon: two case studies from the French final Palaeolithic. British Archaeological Reports International Series 177. Archaeopress, Oxford.

Mourre, V., 2003. Discoide ou pas Discoide? Réflexions sur la pertinence des critères technique définissant le débitage Discoide, in: Peresani, M. (Ed.), Discoid Lithic Technology: Advances and Implications. BAR International Series 1120. Archaeopress, Oxford, pp. 1-18.

Mourre, V., 1996. Les industries en quartz au Paléolithique. Terminologie, méthodologie et technologie. Paléo 8, 205-223. https://doi.org/10.3406/pal.1996.1160

Mourre, V., 1994. Les industries en quartz au Paléolithique moyen. Approche technologique de séries du Sud-Ouest de la France. Université de Paris X.

Odell, G.H., 1996. Economizing behavior and the concept of "curation," in: Odell, G.H. (Ed.), Stone Tools. Theoretical Insights into Human Prehistory. Plenum Press, New York, pp. 51-80.

Odell, G.H., 1981. The mechanism of use-breakage of stone tools: some testable hypothesis. J. F. Archaeol. 8, 197-209.

Ortega, D., Maroto, J., 2001. Matières premières et technologie lithique du Moustérien final de la grotte des Ermitons (Pyrénées Méditerranéennes), in: Aubry, T., Carvalho, A.F. (Eds.), Les Premiers Hommes Modernes de La Péninsule Ibérique. Actes Du Colloque de La Commission VIII de 1'UISPP. Vila Nova de Foz Coa, 1998. Instituto Português de Arqueologia, pp. 69-76.

Palmqvist, P., Martínez-Navarro, B., Toro, I., Patrocinio Espigares, M., Ros-Montoya, S., Torregrosa, V., Pérez-Claros, J.A., 2005. Réévaluation de la présence humaine au Pléistocène inférieur dans le Sud de l'Espagne. L' Anthropol. 109, 411-450. https://doi.org/10.1016/j.anthro.2005.06.001

Pelegrin, J., Karlin, C., Bodu, P., 1988. «Chaînes opératoires»: un outil pour le préhistorien. Technologie préhistorique. Notes Monogr. Tech.

Peresani, M. (Ed.), 2003. Discoid Lithic Technology: Advances and Implications. BAR International Series 1120. Archaeopress.

Picin, A., Vaquero, M., 2016. Flake productivity in the Levallois recurrent centripetal and discoid technologies: New insights from experimental and archaeological lithic series. J. Archaeol. Sci. Reports 8, 70-81. https://doi.org/10.1016/j.jasrep.2016.05.062

Picin, A., Vaquero, M., Weniger, G.C., Carbonell, E., 2014. Flake morphologies and patterns of core configuration at the Abric Romaní rock-shelter: A geometric morphometric approach. Quat. Int. 350, 84-93. https://doi.org/10.1016/j.quaint.2014.05.004

Riel-Salvatore, J., Barton, C.M., 2004. Late Pleistocene technology, economic behavior, and landuse dynamics in southern Italy. Am. Antiq. 69, 257-274.

Rios-Garaizar, J., Maidagan, D.G., Gómez-Olivencia, A., Iriarte, E., Arceredillo-Alonso, D., IriarteChiapusso, M.J., Garcia-Ibaibarriaga, N., García-Moreno, A., Gutierrez-Zugasti, I., Torres, T., Aranburu, A., Arriolabengoa, M., Bailón, S., Murelaga, X., Ordiales, A., Ortiz, J.E., Rofes, J., Pedro, Z.S., 2015. Short-term Neandertal occupations in the late Middle Pleistocene of Arlanpe (Lemoa, northern Iberian Peninsula). Comptes Rendus - Palevol 14, 233-244. https://doi.org/10.1016/j.crpv.2014.11.006

Rodríguez-Alvarez, X.P., 2016. The use of quartz during the Lower Palaeolithic in northeastern Iberia. Quat. Int. 424, 69-83. https://doi.org/10.1016/j.quaint.2016.01.022

Rodríguez-Rellan, C., 2016. Variability of the rebound hardness as a proxy for detecting the levels 
of continuity and isotropy in archaeological quartz. Quat. Int. 424, 191-211.

https://doi.org/10.1016/j.quaint.2015.12.085

Romagnoli, F., 2015. A second life: Recycling production waste during the Middle Palaeolithic in layer L at Grotta del Cavallo (Lecce, Southeast Italy). Quat. Int. 361, 200-211. https://doi.org/10.1016/j.quaint.2014.07.033

Romagnoli, F., Bargalló, A., Chacón, M.G., Gomez de Soler, B., Vaquero, M., 2016. Testing a hypothesis about the importance of the quality of raw material on technological changes at Abric Romaní (Capellades, Spain): Some considerations using high-resolution technoeconomic perspective. J. lithic Stud. 3. https://doi.org/10.2218/jls.v4i2.1443

Rots, V., 2010. Prehension and Hafting Traces on Flint Tools: A Methodology. Leuven University Press, Leuven.

Rots, V., Hardy, B.L., 2015. Residue and Microwear Analyses of the Stone Artifacts from Schöningen. J. Hum. Evol. 89, 298-308. https://doi.org/10.1016/j.jhevol.2015.07.005

Santagata, C., Moncel, M.-H., Raynal, J.-P., 2017. Neanderthals and volcanic rocks. Opportunistic behaviour or optimized management? Comptes Rendus Palevol 16, 474-487. https://doi.org/https://doi.org/10.1016/j.crpv.2016.12.001

Shimelmitz, R., Kuhn, S.L., 2018. The toolkit in the core: There is more to Levallois production than predetermination. Quat. Int. 464, 81-91. https://doi.org/10.1016/j.quaint.2017.08.011

Shott, M.J., 1996. An exegesis of the curation concept. J. Anthropol. Res. 52, 1259-280.

Solodenko, N., Zupancich, A., Cesaro, S.N., Marder, O., Lemorini, C., Barkai, R., 2015. Fat Residue and Use-Wear Found on Acheulian Biface and Scraper Associated with Butchered Elephant Remains at the Site of Revadim, Israel. PLoS One 10. https://doi.org/10.1371/journal.pone.0118572

Stiner, M.C., 2013. An Unshakable Middle Paleolithic? Curr. Anthropol. 54, S288-S304. https://doi.org/10.1086/673285

Tallavaara, M., Manninen, M. a., Hertell, E., Rankama, T., 2010. How flakes shatter: A critical evaluation of quartz fracture analysis. J. Archaeol. Sci. 37, 2442-2448. https://doi.org/10.1016/j.jas.2010.05.005

Thiébaut, C., Mourre, V., Chalard, P., Colonge, D., Coudenneau, A., Deschamps, M., SaccoSonador, A., 2012. Lithic technology of the final Mousterian on both sides of the Pyrenees. Quat. Int. 247, 182-198. https://doi.org/10.1016/j.quaint.2011.05.028

Tixier, J., 1978. Méthod pur l'étude des outillages lithiques. Notice sur le travaux scientifiques présentés en vue du grade de Docteur en lettres. Université de Paris X - Nanterre.

Tixier, J., Turq, A., 1999. Kombewa et alii. Paléo 11, 135-143. https://doi.org/10.3406/pal.1999.1174

Torrence, R., 1983. Time budgeting and hunter-gatherer technology, in: Bailey, G. (Ed.), Pleistocene Hunters and Gatherers in Europe. Cambridge University Press, New York, pp. 1122.

Van Gijn, A.L., 2014. Science and interpretation in microwear studies. J. Archaeol. Sci. 48, 166169. https://doi.org/10.1016/j.jas.2013.10.024

Vaquero, M., Carbonell, E., 2003. A temporal perspective on the variability of the discoid method in the Iberian Peninsula, in: Peresani, M. (Ed.), Discoid Lithic Technology: Advances and Implications. BAR International Series 1120. Archaeopress, pp. 67-82.

Vaquero, M., Chacón, M.G., García-Antón, M.D., Gómez de Soler, B., Martínez, K., Cuartero, F., 2012. Time and space in the formation of lithic assemblages: The example of Abric Romaní Level J. Quat. Int. 247, 162-181. https://doi.org/10.1016/j.quaint.2010.12.015

Vaquero, M., Romagnoli, F., 2017. Searching for Lazy People: the Significance of Expedient Behavior in the Interpretation of Paleolithic Assemblages. J. Archaeol. Method Theory. https://doi.org/10.1007/s10816-017-9339-x

Vietti, A., 2016. Combined Electron Spin Resonance and U-series dating (ESR/U-series) of fossil tooth enamel: application to dental remains from different Palaeolithic Italian sites. Universtià 
degli Studi di Torino.

Villa, G., Giacobini, G., 2005. I resti umani neandertaliani del Monte Fenera, in: Fantoni, R., Cerri, R., Dellarole, E. (Eds.), D’acqua e Di Pietra. II Monte Fenera e Le Sue Collezioni Museali. Associazione culturale ZEISCIU Centro Studi, Alagna Valsesia, pp. 234-238.

Villa, G., Giacobini, G., 1993. Borgosesia, Monte Fenera. Denti neandertaliani dalla grotta Ciota Ciara. Quad. della Soprintend. Archeol. del Piemonte 11, 300-303.

Visentin, D., Fontana, F., Bertola, S., Berruti, G.L.F., Ziggiotti, S., 2016. The first Holocene occupation of the Emilian Po plain : techno-economical data from the Sauveterrian site of Collecchio (Parma), in: Incontri Annuali di Preistoria e Protostoria, 1. pp. 86-88.

Wilkins, J., Schoville, B.J., Brown, K.S., Chazan, M., 2015. Kathu Pan 1 points and the assemblage-scale, probabilistic approach: a response to Rots and Plisson, "Projectiles and the abuse of the use-wear method in a search for impact." J. Archaeol. Sci. 54, 294-299. https://doi.org/10.1016/j.jas.2014.12.003

Wiśniewski, A., 2014. The beginnings and diversity of Levallois methods in the Early Middle Palaeolithic of Central Europe. Quat. Int. 326-327, 364-380. https://doi.org/10.1016/j.quaint.2013.10.027

Zambaldi, M., Angelucci, D.E., Arzarello, M., 2016. First data on stratigraphy and formation processes at Ciota Ciara cave (Monte Fenera, Borgosesia, Vercelli), in: Il Paleolitico e Il Mesolitico in Italia: Nuove Ricerche e Prospettive Di Studio The Palaeolithic and Mesolithic in Italy: New Research and Perspectives. pp. 27-28.

Zupancich, A., Lemorini, C., Gopher, A., Barkai, R., 2016. On Quina and demi-Quina scraper handling: Preliminary results from the late Lower Paleolithic site of Qesem Cave, Israel. Quat. Int. 398, 94-102. https://doi.org/10.1016/j.quaint.2015.10.101 
Tab. 1

\begin{tabular}{|c|c|c|c|c|c|c|}
\hline & Cores & Flakes & $\begin{array}{c}\text { Retouched } \\
\text { tools }\end{array}$ & Debris & $\begin{array}{c}\text { Unworked } \\
\text { blanks }\end{array}$ & Total \\
\hline S.U. 13 & $\begin{array}{c}35 \\
3,9 \%\end{array}$ & $\begin{array}{c}511 \\
57,4 \%\end{array}$ & $\begin{array}{c}19 \\
2,1 \%\end{array}$ & $\begin{array}{c}324 \\
36,4 \%\end{array}$ & $\begin{array}{c}2 \\
0,2 \%\end{array}$ & 891 \\
\hline S.U. 14 & $\begin{array}{c}132 \\
3,3 \%\end{array}$ & $\begin{array}{c}2686 \\
67,2 \%\end{array}$ & $\begin{array}{c}74 \\
1,9 \%\end{array}$ & $\begin{array}{c}1090 \\
27,3 \%\end{array}$ & $\begin{array}{c}17 \\
0,4 \%\end{array}$ & 3999 \\
\hline S.U. 15 & $\begin{array}{c}54 \\
3 \%\end{array}$ & $\begin{array}{c}1094 \\
61,2 \%\end{array}$ & $\begin{array}{c}27 \\
1,5 \%\end{array}$ & $\begin{array}{c}585 \\
32,7 \%\end{array}$ & $\begin{array}{c}28 \\
1,6 \%\end{array}$ & 1788 \\
\hline S.U. 103 & $\begin{array}{c}13 \\
3 \%\end{array}$ & $\begin{array}{c}238 \\
55,6 \%\end{array}$ & $\begin{array}{c}9 \\
2,1 \%\end{array}$ & $\begin{array}{c}157 \\
36,7 \%\end{array}$ & $\begin{array}{c}11 \\
2,6 \%\end{array}$ & 428 \\
\hline Total & $\begin{array}{c}234 \\
3,2 \%\end{array}$ & $\begin{array}{c}4529 \\
63,8 \%\end{array}$ & $\begin{array}{c}129 \\
1,8 \%\end{array}$ & $\begin{array}{c}2156 \\
30,4 \%\end{array}$ & $\begin{array}{c}\mathbf{5 8} \\
\mathbf{0 , 8 \%}\end{array}$ & 7106 \\
\hline
\end{tabular}

Tab. 2

\begin{tabular}{c|ccc|c}
\hline & Opportunistic & Levallois & Discoid & Total \\
\hline Quartz & 39 & 9 & 6 & $\mathbf{5 4}$ \\
Spongolite/flint & 13 & 4 & 2 & $\mathbf{1 9}$ \\
\hline Total & $\mathbf{5 2}$ & $\mathbf{1 3}$ & $\mathbf{8}$ & $\mathbf{7 3}$
\end{tabular}


Tab. 3

\begin{tabular}{|c|c|c|c|c|c|c|c|c|c|c|c|c|c|}
\hline & \multicolumn{4}{|c|}{ Spongolite } & \multicolumn{4}{|c|}{ Vein quartz } & \multicolumn{4}{|c|}{ Flint } & \\
\hline & T. 5 & L. 5 & T. 10 & L. 10 & T. 5 & L. 5 & T. 10 & L. 10 & T. 5 & L. 5 & T. 10 & L. 10 & \\
\hline Butchering & 1 & 2 & & 2 & 2 & 2 & & 1 & 1 & 1 & 1 & 1 & \\
\hline Fresh hide & & & & & & 1 & 1 & & 1 & & 1 & & \\
\hline Bone & 1 & & 1 & & 1 & 1 & 1 & & 1 & & 1 & & \\
\hline Wood & & 1 & 1 & & & 1 & & 1 & 1 & 1 & & 1 & \\
\hline Tot. & 2 & 3 & 2 & 2 & 3 & 5 & 2 & 2 & 4 & 3 & 4 & 2 & Tot. \\
\hline $\begin{array}{l}\text { Tot. for each } \\
\text { raw material }\end{array}$ & & & 9 & & & & 12 & & & & 14 & & 35 \\
\hline
\end{tabular}

Tab. 4

\begin{tabular}{|c|c|c|c|c|c|c|c|}
\hline & Quartz & Spongolite & Grey flint & Rhyolite & Radiolarite & Others & Total \\
\hline S.U. 13 & $\begin{array}{c}768 \\
86,2 \%\end{array}$ & $\begin{array}{c}59 \\
6,6 \%\end{array}$ & $\begin{array}{c}52 \\
5,8 \%\end{array}$ & $\begin{array}{c}1 \\
0,1 \%\end{array}$ & $\begin{array}{c}8 \\
0,9 \%\end{array}$ & $\begin{array}{c}3 \\
0,3 \%\end{array}$ & 891 \\
\hline S.U. 14 & $\begin{array}{l}3119 \\
78 \%\end{array}$ & $\begin{array}{c}508 \\
12,7 \%\end{array}$ & $\begin{array}{c}210 \\
5,3 \%\end{array}$ & $\begin{array}{c}50 \\
1,3 \%\end{array}$ & $\begin{array}{c}67 \\
1,7 \%\end{array}$ & $\begin{array}{c}45 \\
1,1 \%\end{array}$ & 3999 \\
\hline S.U. 15 & $\begin{array}{c}905 \\
50,6 \%\end{array}$ & $\begin{array}{c}793 \\
44,4 \%\end{array}$ & $\begin{array}{c}28 \\
1,6 \%\end{array}$ & $\begin{array}{c}21 \\
1,2 \%\end{array}$ & $\begin{array}{c}22 \\
1,2 \%\end{array}$ & $\begin{array}{c}19 \\
1,1 \%\end{array}$ & 1788 \\
\hline S.U. 103 & $\begin{array}{l}227 \\
53 \%\end{array}$ & $\begin{array}{c}141 \\
32,9 \%\end{array}$ & $\begin{array}{c}57 \\
13,3 \%\end{array}$ & $\begin{array}{c}1 \\
0,2 \%\end{array}$ & - & $\begin{array}{c}2 \\
0,4 \%\end{array}$ & 428 \\
\hline Total & $\begin{array}{c}5019 \\
70,6 \%\end{array}$ & $\begin{array}{c}1501 \\
21,1 \%\end{array}$ & $\begin{array}{c}347 \\
4,9 \%\end{array}$ & $\begin{array}{r}73 \\
1 \%\end{array}$ & $\begin{array}{c}97 \\
1,4 \%\end{array}$ & $\begin{array}{r}69 \\
1 \%\end{array}$ & 7106 \\
\hline
\end{tabular}

Tab. 5

\begin{tabular}{|c|c|c|c|c|c|c|c|}
\hline & $\begin{array}{l}\text { Complete } \\
\text { flakes }\end{array}$ & $\begin{array}{l}\text { Incomplete } \\
\text { flakes }\end{array}$ & $\begin{array}{c}\text { Lateral } \\
\text { fragments }\end{array}$ & $\begin{array}{c}\text { Distal } \\
\text { fragments }\end{array}$ & $\begin{array}{l}\text { Proximal } \\
\text { fragments }\end{array}$ & $\begin{array}{c}\text { Mesial } \\
\text { fragments }\end{array}$ & Total \\
\hline S.U. 13 & $\begin{array}{c}108 \\
17,7 \%\end{array}$ & $\begin{array}{c}78 \\
12,8 \%\end{array}$ & $\begin{array}{c}198 \\
32,5 \%\end{array}$ & $\begin{array}{c}119 \\
19,6 \%\end{array}$ & $\begin{array}{c}53 \\
8,7 \%\end{array}$ & $\begin{array}{c}53 \\
8,7 \%\end{array}$ & 609 \\
\hline S.U. 14 & $\begin{array}{c}793 \\
28,7 \%\end{array}$ & $\begin{array}{c}456 \\
16,5 \%\end{array}$ & $\begin{array}{c}335 \\
12,1 \%\end{array}$ & $\begin{array}{c}647 \\
23,4 \%\end{array}$ & $\begin{array}{c}309 \\
11,3 \%\end{array}$ & $\begin{array}{l}220 \\
8 \%\end{array}$ & 2760 \\
\hline S.U. 15 & $\begin{array}{c}395 \\
35,3 \%\end{array}$ & $\begin{array}{c}158 \\
14,1 \%\end{array}$ & $\begin{array}{c}93 \\
8,3 \%\end{array}$ & $\begin{array}{c}256 \\
22,8 \%\end{array}$ & $\begin{array}{c}147 \\
13,1 \%\end{array}$ & $\begin{array}{c}72 \\
6,4 \%\end{array}$ & 1121 \\
\hline S.U. 103 & $\begin{array}{c}70 \\
28,5 \%\end{array}$ & $\begin{array}{c}34 \\
13,8 \%\end{array}$ & $\begin{array}{c}21 \\
8,6 \%\end{array}$ & $\begin{array}{c}63 \\
25,6 \%\end{array}$ & $\begin{array}{c}38 \\
15,4 \%\end{array}$ & $\begin{array}{c}20 \\
8,1 \%\end{array}$ & 246 \\
\hline Total & $\begin{array}{c}1366 \\
28,8 \%\end{array}$ & $\begin{array}{c}726 \\
15,3 \%\end{array}$ & $\begin{array}{c}647 \\
13,7 \%\end{array}$ & $\begin{array}{c}1085 \\
22,9 \%\end{array}$ & $\begin{array}{c}547 \\
11,5 \%\end{array}$ & $\begin{array}{c}365 \\
7,8 \%\end{array}$ & 4736 \\
\hline
\end{tabular}


Tab. 6

\begin{tabular}{|c|c|c|c|c|c|c|c|}
\hline & Total & Lateral & Distal & Proximal & Mesial & Absent & Total \\
\hline S.U. 13 & $\begin{array}{c}33 \\
6,2 \%\end{array}$ & $\begin{array}{c}42 \\
7,9 \%\end{array}$ & $\begin{array}{c}12 \\
2,3 \%\end{array}$ & $\begin{array}{c}9 \\
1,7 \%\end{array}$ & $\begin{array}{c}3 \\
0,6 \%\end{array}$ & $\begin{array}{c}431 \\
81,3 \%\end{array}$ & 530 \\
\hline S.U. 14 & $\begin{array}{c}125 \\
4,5 \%\end{array}$ & $\begin{array}{c}283 \\
10,3 \%\end{array}$ & $\begin{array}{c}51 \\
1,8 \%\end{array}$ & $\begin{array}{c}29 \\
1,1 \%\end{array}$ & $\begin{array}{c}15 \\
0,5 \%\end{array}$ & $\begin{array}{c}2257 \\
81,8 \%\end{array}$ & 2760 \\
\hline S.U. 15 & $\begin{array}{c}29 \\
2,6 \%\end{array}$ & $\begin{array}{c}93 \\
8,3 \%\end{array}$ & $\begin{array}{c}33 \\
2,9 \%\end{array}$ & $\begin{array}{c}8 \\
0,7 \%\end{array}$ & $\begin{array}{c}4 \\
0,4 \%\end{array}$ & $\begin{array}{c}954 \\
85,1 \%\end{array}$ & 1121 \\
\hline S.U. 103 & $\begin{array}{c}14 \\
5,7 \%\end{array}$ & $\begin{array}{c}27 \\
11,1 \%\end{array}$ & $\begin{array}{c}9 \\
3,6 \%\end{array}$ & $\begin{array}{c}4 \\
1,6 \%\end{array}$ & $\begin{array}{c}1 \\
0,4 \%\end{array}$ & $\begin{array}{c}191 \\
77,6 \%\end{array}$ & 246 \\
\hline Total & $\begin{array}{c}201 \\
4,3 \%\end{array}$ & $\begin{array}{c}445 \\
9,5 \%\end{array}$ & $\begin{array}{c}105 \\
2,3 \%\end{array}$ & $\begin{array}{c}50 \\
1,1 \%\end{array}$ & $\begin{array}{c}23 \\
0,5 \%\end{array}$ & $\begin{array}{c}3833 \\
82,3 \%\end{array}$ & 4657 \\
\hline
\end{tabular}

Tab. 7

\begin{tabular}{|c|c|c|c|c|c|c|c|c|}
\hline & Unipolar & Bipolar & Crossed & Orthogonal & Convergent & Centripetal & Indet. & Total \\
\hline S.U. 13 & $\begin{array}{c}228 \\
43,0 \%\end{array}$ & $\begin{array}{c}9 \\
1,7 \%\end{array}$ & $\begin{array}{c}83 \\
15,7 \%\end{array}$ & $\begin{array}{c}6 \\
1,1 \%\end{array}$ & $\begin{array}{c}1 \\
0,2 \%\end{array}$ & $\begin{array}{c}32 \\
6,0 \%\end{array}$ & $\begin{array}{c}171 \\
32,3 \%\end{array}$ & 530 \\
\hline S.U. 14 & $\begin{array}{c}1298 \\
47,1 \%\end{array}$ & $\begin{array}{c}64 \\
2,3 \%\end{array}$ & $\begin{array}{c}420 \\
15,2 \%\end{array}$ & $\begin{array}{c}52 \\
1,9 \%\end{array}$ & $\begin{array}{c}23 \\
0,8 \%\end{array}$ & $\begin{array}{c}350 \\
12,7 \%\end{array}$ & $\begin{array}{c}553 \\
20,0 \%\end{array}$ & 2760 \\
\hline S.U. 15 & $\begin{array}{c}478 \\
42,6 \%\end{array}$ & $\begin{array}{c}36 \\
3,2 \%\end{array}$ & $\begin{array}{c}159 \\
14,2 \%\end{array}$ & $\begin{array}{c}42 \\
3,7 \%\end{array}$ & $\begin{array}{c}4 \\
0,4 \%\end{array}$ & $\begin{array}{c}113 \\
10,1 \%\end{array}$ & $\begin{array}{c}289 \\
25,8 \%\end{array}$ & 1121 \\
\hline $\begin{array}{l}\text { S.U. } \\
103\end{array}$ & $\begin{array}{c}84 \\
34,1 \%\end{array}$ & $\begin{array}{c}6 \\
2,4 \%\end{array}$ & $\begin{array}{c}26 \\
10,7 \%\end{array}$ & - & $\begin{array}{c}1 \\
0,4 \%\end{array}$ & $\begin{array}{c}19 \\
7,7 \%\end{array}$ & $\begin{array}{c}110 \\
44,7 \%\end{array}$ & 246 \\
\hline Total & $\begin{array}{c}2088 \\
44,9 \%\end{array}$ & $\begin{array}{c}115 \\
2,5 \%\end{array}$ & $\begin{array}{c}688 \\
14,8 \%\end{array}$ & $\begin{array}{c}100 \\
2,1 \%\end{array}$ & $\begin{array}{c}29 \\
0,6 \%\end{array}$ & $\begin{array}{c}514 \\
11,0 \%\end{array}$ & $\begin{array}{c}1123 \\
24,1 \%\end{array}$ & 4657 \\
\hline
\end{tabular}


Tab. 8

\begin{tabular}{|c|c|c|c|c|c|c|c|c|}
\hline $\begin{array}{c}\text { Raw } \\
\text { material } \\
\end{array}$ & Opp. & Discoid & Levallois & $\begin{array}{c}\text { Kombewa } \\
\text { s.l. } \\
\end{array}$ & Indet. & $\begin{array}{c}\text { Retouch } \\
\text { flakes }\end{array}$ & Debris & Tot. \\
\hline \multirow[t]{2}{*}{ Quartz } & $\mathrm{F} .=371$ & $\mathrm{~F} .=31$ & F. $=9$ & $\mathrm{~F} .=4$ & F. $=28$ & & & \\
\hline & C. $=24$ & C. $=5$ & C. $=2$ & C. $=-$ & C. $=-$ & & & \\
\hline Tot. & 395 & 36 & 11 & 4 & 28 & 17 & 276 & 767 \\
\hline$\%$ & $44,4 \%$ & $4,0 \%$ & $1,2 \%$ & $0,4 \%$ & $3,1 \%$ & $1,9 \%$ & $31,0 \%$ & $86,3 \%$ \\
\hline \multirow[t]{2}{*}{ Spongolite } & F. $=9$ & F. $=7$ & F. $=1$ & F. $=-$ & F. $=4$ & & & \\
\hline & C. $=1$ & C. $=2$ & C. $=-$ & C. $=-$ & C. $=-$ & & & \\
\hline Tot. & 10 & 9 & 1 & - & 4 & 13 & 21 & 58 \\
\hline$\%$ & $1,1 \%$ & $1,0 \%$ & $0,1 \%$ & - & $0,4 \%$ & $1,5 \%$ & $2,4 \%$ & $6,5 \%$ \\
\hline \multirow[t]{2}{*}{ Grey flint } & $\mathrm{F} .=25$ & F. $=-$ & $\mathrm{F} .=-$ & $\mathrm{F} .=-$ & F. $=-$ & & & \\
\hline & C. $=-$ & C. $=-$ & C. $=-$ & C. $=-$ & C. $=-$ & & & \\
\hline Tot. & 25 & - & - & - & - & 4 & 23 & 52 \\
\hline$\%$ & $2,8 \%$ & - & - & - & - & $0,4 \%$ & $2,6 \%$ & $5,8 \%$ \\
\hline \multirow[t]{2}{*}{ Others } & $\mathrm{F} .=1$ & $\mathrm{~F} .=-$ & F. $=-$ & F. $=-$ & $\mathrm{F} .=2$ & & & \\
\hline & C. $=-$ & C. $=-$ & C. $=-$ & C. $=1$ & C. $=-$ & & & \\
\hline Tot. & 1 & - & - & 1 & 2 & 4 & 4 & 12 \\
\hline$\%$ & $0,1 \%$ & - & - & $0,1 \%$ & $0,2 \%$ & $0,4 \%$ & $0,4 \%$ & $1,3 \%$ \\
\hline Total & 431 & 45 & 12 & 5 & 34 & 38 & 324 & 889 \\
\hline$\%$ & $48,5 \%$ & $5,1 \%$ & $1,3 \%$ & $0,6 \%$ & $3,8 \%$ & $4,3 \%$ & $36,4 \%$ & $100,0 \%$ \\
\hline
\end{tabular}


Tab. 9

\begin{tabular}{|c|c|c|c|c|c|c|c|c|}
\hline $\begin{array}{c}\text { Raw } \\
\text { material }\end{array}$ & Opp. & Discoid & Levallois & $\begin{array}{c}\text { Kombewa } \\
\text { s.l. }\end{array}$ & Indet. & $\begin{array}{c}\text { Retouch } \\
\text { flakes }\end{array}$ & Debr. & Tot. \\
\hline \multirow[t]{2}{*}{ Quartz } & F. $=1437$ & F. $=252$ & F. $=137$ & F. $=17$ & F. $=296$ & & & \\
\hline & C. $=71$ & C. $=33$ & C. $=5$ & C. $=2$ & C. $=-$ & & & \\
\hline Tot. & 1508 & 285 & 142 & 19 & 296 & 62 & 807 & 3119 \\
\hline$\%$ & $37,9 \%$ & $7,2 \%$ & $3,6 \%$ & $0,5 \%$ & $7,4 \%$ & $1,6 \%$ & $20,3 \%$ & $78,3 \%$ \\
\hline \multirow[t]{2}{*}{ Spongolite } & F. $=141$ & F. $=24$ & F. $=12$ & F. $=4$ & $\mathrm{~F} .=59$ & & & \\
\hline & C. $=15$ & C. $=2$ & C. $=-$ & C. $=-$ & C. $=-$ & & & \\
\hline Tot. & 156 & 26 & 12 & 4 & 59 & 49 & 191 & 497 \\
\hline$\%$ & $3,9 \%$ & $0,7 \%$ & $0,3 \%$ & $0,1 \%$ & $1,5 \%$ & $1,2 \%$ & $4,8 \%$ & $12,5 \%$ \\
\hline \multirow[t]{2}{*}{ Grey flint } & $\mathrm{F} .=73$ & F. $=8$ & F. $=7$ & F. $=1$ & F. $=20$ & & & \\
\hline & C. $=-$ & C. $=2$ & C. $=1$ & C. $=-$ & C. $=-$ & & & \\
\hline Tot. & 73 & 10 & 8 & 1 & 20 & 35 & 63 & 210 \\
\hline$\%$ & $1,8 \%$ & $0,3 \%$ & $0,2 \%$ & $0,03 \%$ & $0,5 \%$ & $0,9 \%$ & $1,6 \%$ & $5,3 \%$ \\
\hline \multirow[t]{2}{*}{$\begin{array}{c}\text { Rhyolite/ } \\
\text { Radiolarite }\end{array}$} & F. $=30$ & F. $=14$ & F. $=15$ & $\mathrm{~F} .=-$ & F. $=11$ & & & \\
\hline & C. $=1$ & C. $=-$ & C. $=-$ & C. $=-$ & C. $=-$ & & & \\
\hline Tot. & 31 & 14 & 15 & - & 11 & 26 & 20 & 117 \\
\hline$\%$ & $0,8 \%$ & $0,4 \%$ & $0,4 \%$ & - & $0,3 \%$ & $0,7 \%$ & $0,5 \%$ & $2,9 \%$ \\
\hline \multirow[t]{2}{*}{ Others } & F. $=12$ & F. $=4$ & $\mathrm{~F} .=3$ & $\mathrm{~F} .=-$ & $\mathrm{F} .=3$ & & & \\
\hline & C. $=-$ & C. $=-$ & C. $=-$ & C. $=-$ & C. $=-$ & & & \\
\hline Tot. & 12 & 4 & 3 & - & 3 & 9 & 9 & 40 \\
\hline$\%$ & $0,3 \%$ & $0,1 \%$ & $0,1 \%$ & - & $0,1 \%$ & $0,2 \%$ & $0,2 \%$ & $1,0 \%$ \\
\hline Total & 1780 & 339 & 180 & 24 & 389 & 181 & 1090 & 3983 \\
\hline$\%$ & $44,7 \%$ & $8,5 \%$ & $4,5 \%$ & $0,6 \%$ & $9,8 \%$ & $4,5 \%$ & $27,4 \%$ & $100 \%$ \\
\hline
\end{tabular}


Tab. 10

\begin{tabular}{|c|c|c|c|c|c|c|c|c|}
\hline $\begin{array}{c}\text { Raw } \\
\text { material }\end{array}$ & Opp. & Discoid & Levallois & $\begin{array}{c}\text { Kombewa } \\
\text { s.l. } \\
\end{array}$ & Indet. & $\begin{array}{c}\text { Retouch } \\
\text { flakes }\end{array}$ & Debr. & Tot. \\
\hline \multirow[t]{2}{*}{ Quartz } & F. $=410$ & F. $=64$ & F. $=41$ & F. $=4$ & F. $=84$ & & & \\
\hline & C. $=13$ & C. $=5$ & C. $=2$ & C. $=-$ & C. = - & & & \\
\hline Tot. & 423 & 69 & 43 & 4 & 84 & 17 & 265 & 905 \\
\hline$\%$ & $24,1 \%$ & $3,9 \%$ & $2,4 \%$ & $0,2 \%$ & $4,8 \%$ & $1,0 \%$ & $15,1 \%$ & $51,5 \%$ \\
\hline \multirow[t]{2}{*}{ Spongolite } & F. $=205$ & F. $=31$ & $\mathrm{~F} .=17$ & F. $=5$ & F. $=84$ & & & \\
\hline & C. $=26$ & C. $=4$ & C. $=-$ & C. $=-$ & C. $=-$ & & & \\
\hline Tot. & 231 & 35 & 17 & 5 & 84 & 94 & 299 & 765 \\
\hline$\%$ & $13,1 \%$ & $2,0 \%$ & $1,0 \%$ & $0,3 \%$ & $4,8 \%$ & $5,4 \%$ & $17,0 \%$ & $43,5 \%$ \\
\hline \multirow[t]{2}{*}{ Grey flint } & F. $=8$ & F. $=3$ & F. $=4$ & F. $=-$ & F. $=3$ & & & \\
\hline & C. $=-$ & C. $=-$ & C. $=-$ & C. $=-$ & C. $=-$ & & & \\
\hline Tot. & 8 & 3 & 4 & - & 3 & 5 & 4 & 27 \\
\hline$\%$ & $0,5 \%$ & $0,2 \%$ & $0,2 \%$ & - & $0,2 \%$ & $0,3 \%$ & $0,2 \%$ & $1,5 \%$ \\
\hline \multirow[t]{2}{*}{$\begin{array}{c}\text { Rhyolite } \\
\text { Radiolarite }\end{array}$} & F. $=10$ & F. $=4$ & F. $=4$ & $\mathrm{~F} .=-$ & F. $=4$ & & & \\
\hline & C. $=2$ & C. $=-$ & C. $=-$ & C. $=-$ & C. $=-$ & & & \\
\hline Tot. & 12 & 4 & 4 & - & 4 & 7 & 11 & 43 \\
\hline$\%$ & $0,7 \%$ & $0,2 \%$ & $0,2 \%$ & - & $0,2 \%$ & $0,4 \%$ & $0,6 \%$ & $2,4 \%$ \\
\hline \multirow[t]{2}{*}{ Others } & F. $=7$ & F. $=1$ & F. $=-$ & F. $=-$ & F. $=-$ & & & \\
\hline & C. $=-$ & C. $=-$ & C. $=-$ & C. $=-$ & C. $=-$ & & & \\
\hline Tot. & 7 & 1 & - & - & - & 4 & 6 & 17 \\
\hline$\%$ & $0,4 \%$ & $0,1 \%$ & - & - & - & $0,2 \%$ & $0,3 \%$ & $1,0 \%$ \\
\hline Total & 681 & 112 & 68 & 9 & 175 & 127 & 585 & 1757 \\
\hline$\%$ & $38,8 \%$ & $6,4 \%$ & $3,9 \%$ & $0,5 \%$ & $10,0 \%$ & $7,2 \%$ & $33,3 \%$ & $100 \%$ \\
\hline
\end{tabular}


Tab. 11

\begin{tabular}{|c|c|c|c|c|c|c|c|}
\hline Raw material & Opp. & Discoid & Levallois & Indet. & Retouch flakes & Debris & Total \\
\hline \multirow[t]{2}{*}{ Quartz } & F. $=87$ & $\mathrm{~F} .=13$ & $\mathrm{~F} .=2$ & F. $=23$ & & & \\
\hline & C. $=3$ & C. $=2$ & C. $=1$ & C. $=1$ & & & \\
\hline Tot. & 90 & 15 & 3 & 24 & 16 & 78 & 226 \\
\hline$\%$ & $21,6 \%$ & $3,6 \%$ & $0,7 \%$ & $5,8 \%$ & $3,8 \%$ & $18,7 \%$ & $54,2 \%$ \\
\hline \multirow[t]{2}{*}{ Spongolite } & F. $=36$ & F. $=4$ & F. $=1$ & F. $=17$ & & & \\
\hline & C. $=4$ & C. $=1$ & C. $=-$ & C. $=-$ & & & \\
\hline Tot. & 40 & 5 & 1 & 17 & 11 & 58 & 132 \\
\hline$\%$ & $9,6 \%$ & $1,2 \%$ & $0,2 \%$ & $4,1 \%$ & $2,6 \%$ & $13,9 \%$ & $31,7 \%$ \\
\hline \multirow[t]{2}{*}{ Grey flint } & F. $=27$ & F. $=-$ & F. $=2$ & F. $=4$ & & & \\
\hline & C. $=-$ & C. $=-$ & C. $=-$ & C. $=1$ & & & \\
\hline Tot. & 27 & - & 2 & 5 & 1 & 21 & 56 \\
\hline$\%$ & $6,5 \%$ & - & $0,5 \%$ & $1,2 \%$ & $0,2 \%$ & $5,0 \%$ & $13,4 \%$ \\
\hline \multirow[t]{2}{*}{ Others } & F. $=1$ & F. $=-$ & F. $=-$ & F. $=-$ & & & \\
\hline & C. $=-$ & C. $=-$ & C. $=-$ & C. $=-$ & & & \\
\hline Tot. & 1 & - & - & - & 2 & - & 3 \\
\hline$\%$ & $0,2 \%$ & - & - & - & $0,5 \%$ & - & $0,7 \%$ \\
\hline Total & 158 & 20 & 6 & 46 & 30 & 157 & 417 \\
\hline$\%$ & $37,9 \%$ & $4,8 \%$ & $1,4 \%$ & $11,0 \%$ & $7,2 \%$ & $37,6 \%$ & $100,0 \%$ \\
\hline
\end{tabular}


Tab. 12

\begin{tabular}{|c|c|c|c|c|c|c|}
\hline & \multirow{2}{*}{$\begin{array}{c}\text { Discoid } \\
\text { Long. }\end{array}$} & \multicolumn{3}{|c|}{ Levallois } & \multicolumn{2}{|c|}{ Opp./SSDA } \\
\hline & & Tran. & Long. & Mix. & Tran. & Long. \\
\hline Butchering & & & 1 & & 1 & 3 \\
\hline Fresh Hide & & & & & & 1 \\
\hline Soft animal tissue & & & & & & \\
\hline Bone & & 1 & & & 3 & \\
\hline Wood & 1 & 1 & & 1 & 2 & 1 \\
\hline Non-woody plants & & & & & & \\
\hline Dry hide & & & & & 2 & \\
\hline Indet. & & & & & 1 & \\
\hline Soft & & & & & & \\
\hline Medium Soft & & & & & & \\
\hline Medium Hard & & & & & & \\
\hline Hard & & 1 & & & & \\
\hline Tot & 1 & 3 & 1 & 1 & 9 & 5 \\
\hline
\end{tabular}

Tab. 13

\begin{tabular}{|c|c|c|c|c|c|c|c|}
\hline & \multicolumn{2}{|c|}{ Discoid } & \multicolumn{2}{|c|}{ Levallois } & \multicolumn{3}{|c|}{ Opp./S.S.D.A. } \\
\hline & Tran. & Long. & Tran. & Long. & Tran. & Long. & Indet. \\
\hline Butchering & & & & & & 2 & \\
\hline Fresh Hide & & & & & & & \\
\hline Soft animal tissues & & 1 & & & & 1 & \\
\hline Bone & & & 1 & 1 & & & \\
\hline Wood & & & 1 & & & & \\
\hline Non-woody plants & & & & & 1 & & \\
\hline Dry hide & & & & & & & 1 \\
\hline Indet. & & & & & & & \\
\hline Soft & & & & & & & \\
\hline Medium Soft & & & & & & & \\
\hline Medium Hard & 1 & & & & & & \\
\hline Hard & & & & & & & \\
\hline Tot. & 1 & 1 & 2 & 1 & 1 & 3 & 1 \\
\hline
\end{tabular}


Tab. 14

\begin{tabular}{|l|c|c|c|c|c|c|}
\hline & Denticulates & \multicolumn{2}{|c|}{ Sidescrapers } & \multicolumn{2}{c|}{ Notches } & Quinson point \\
\hline & Tran. & Tran. & Long. & Tran. & Long. & Indet. \\
\hline Butchering & & & 1 & & 1 & \\
\hline Hide & 1 & & & & & \\
\hline Wood & & 1 & 2 & & & \\
\hline Non-woody plant & & 1 & & & & \\
\hline Dry Hide & & & & 1 & & 1 \\
\hline $\begin{array}{l}\text { Medium hard } \\
\text { material }\end{array}$ & 1 & & & 1 & & 1 \\
\hline Tot. for typology & $\mathbf{2}$ & \multicolumn{2}{|c|}{$\mathbf{5}$} & \multicolumn{2}{|c|}{$\mathbf{3}$} & 1 \\
\hline
\end{tabular}




\section{Caption to figures}

Fig. 1. Location of the Ciota Ciara cave. A: west side of Monte Fenera with position of the Ciota Ciara cave; B: interior of the cave; C: map showing the location of primary outcrops and secondary deposits of the main lithic raw materials exploited at the Ciota Ciara cave (from Daffara et al. 2019).

Fig. 2. Planimetry of the Ciota Ciara cave showing the areas investigated during the 50s and the 60s and detail of the present archaeological excavation (modified from Daffara et al., 2019).

Fig. 3. Stratigraphic sequence of the Ciota Ciara cave (Angelucci et al., 2018).

Fig. 4. Experimental work completed on a wild boar carcass: a, d, e) butchering and skinning activities; b) skin processing; c) data recording (raw material, time of use, direction of the gesture and material worked).

Fig. 5. Ciota Ciara cave. Opportunistic reduction sequences: (a) multidirectional core on fluvial pebble; (b) opportunistic core; (c) connection between the proximal and the distal part of an opportunistic flake with neocortical dorsal face; (d) opportunistic core; (e) lateral fragment (siret accident) of S.S.D.A. flake with orthogonal negatives on the dorsal face; (f) opportunistic flake with neocortical dorsal face probably corresponding to the initialization of a vein quartz pebble; $(\mathrm{g})$ opportunistic flake with lateral neocortex issued from the exploitation of a small quartz pebble; (h-j) opportunistic spongolite cores showing the preferential exploitation of spongolite slabs according to their thickness. On the top right: schematic representation of the main features of the Ciota Ciara cave opportunistic reduction strategies.

Fig. 6. Ciota Ciara cave. Levallois products and cores: (a) Mousetrian point; (b) preferential Levallois flake; (c - g) recurrent centripetal Levallois flake; $(\mathrm{h}, \mathrm{l})$ preferential Levallois core; (i, j, k) recurrent centripetal Levallois core. On the top right: dimensional analysis of Levallois cores and products. Fragmented flakes are not considered as well as level 103, where the scarcity of complete Levallois flakes does not make this kind of analysis significative.

Fig. 7. Ciota Ciara cave. Discoid products and cores. (a-c) spongolite discoid flakes; (d, e) vein quartz discoid flakes; (f-h) bifacial discoid cores; (i) unifacial discoid core with neocortical striking platform surface; (j) bifacial discoid core on flake; (k) unifacial discoid core. On the top right: dimensional analysis of discoid flakes and cores. Fragmented flakes are not considered as well as level 103, where the scarcity of complete discoid flakes does not make this kind of analysis significative.

Fig. 8. Ciota Ciara cave. Examples of use-wear traces identified on the experimental collection: (a, b) natural marks on the edges of quartz unused flake; (c) wear traces on a quartz flake used for boneworking: polish with domed topography, micro holes, edge rim worn down, micro scars and striae; (d) wear traces on a quartz flake used for woodworking: domed topography, micro holes and edge rounding. (modified from Daffara et al., 2018).

Fig. 9. Ciota Ciara cave. Use-wear traces on vein quartz artefacts. (A) notch with wear traces interpreted as dry hide working, probably with tanning agents. (B) unretouched flake with use-wear traces interpreted as bone scraping: (b) the edge rim is worn down and polished; (c) cracks and latent fracture typical of hard material working.

Fig. 10. Ciota Ciara cave. Use-wear traces on flint artefacts. (A) sidescraper showing use-wears interpreted as cutting of non-woody plants: 1) band of polish with a closed linkage of its topography; 2) detail of a latent fracture. (B) sidescraper: 3) use-wears interpreted as the result of an 
indeterminable motion on hide; 4) detail of the invasive use-wear traces. C) unretouched flake showing use wear traces interpreted as the result of a longitudinal motion linked to butchering: 5) fleshy tissues and fresh hide; 6) detail of the rounded edge with traces of rough polish (fleshy tissues traces).

\section{Caption to tables}

Tab. 1. Ciota Ciara cave. General composition of the lithic assemblage.

Tab. 2. Ciota Ciara cave. Lithic artefacts from level 14 selected for the use-wear analysis.

Tab. 3. Items used for the experimental collection divided by action (T: transversal; L: longitudinal), time of use (5: 5 minutes; 10: 10 minutes) and raw material

Tab. 4. Ciota Ciara cave. Proportion of the lithic raw materials present in each archaeological layer.

Tab. 5. Ciota Ciara cave. Rate of fragmentation of the knapping products in each archaeological layer.

Tab. 6. Ciota Ciara cave. Presence and position of cortical and neocortical surfaces on the dorsal faces of the flakes from the four considered archaeological layers.

Tab. 7. Ciota Ciara cave. Direction of the knapping scars visible on the dorsal faces of the flakes.

Tab. 8. Ciota Ciara cave. Level 13: raw materials and débitage methods. F. = flakes; C. = cores.

Tab. 9. Ciota Ciara cave. Level 14: raw materials and débitage methods. F. $=$ flakes; C. $=$ cores.

Tab. 10. Ciota Ciara cave. Level 15: raw materials and débitage methods. F. $=$ flakes; C. $=$ cores.

Tab. 11. Ciota Ciara cave. Level 103: raw materials and débitage methods. F. $=$ flakes; $\mathrm{C} .=$ cores.

Tab. 12. Use-wear traces on vein quartz lithic artefacts from S.U. 14 grouped by action, knapping method and worked material. $($ Tran. $=$ transversal action; Long. $=$ longitudinal action; Mix $=$ mixed action; Indet. $=$ indeterminate action ; Opp. = opportunistic method; S.S.D.A.= Système par surface de débitage alterné).

Tab. 13. Use-wear traces on flint lithic artefacts of S.U. 14 grouped by action, knapping method and worked material. (Tran. $=$ transversal action; Long. $=$ longitudinal action; Mix $=$ mixed action; Indet. $=$ indeterminate action ; Opp. = opportunistic method; S.S.D.A.= Système par surface de débitage alterné).

Tab. 14. Use-wear traces on the formal tools of S.U. 14 grouped by action and worked material. (Tran. $=$ transversal action; Long. $=$ longitudinal action; Indet. $=$ indeterminate action). 
Fig. 1
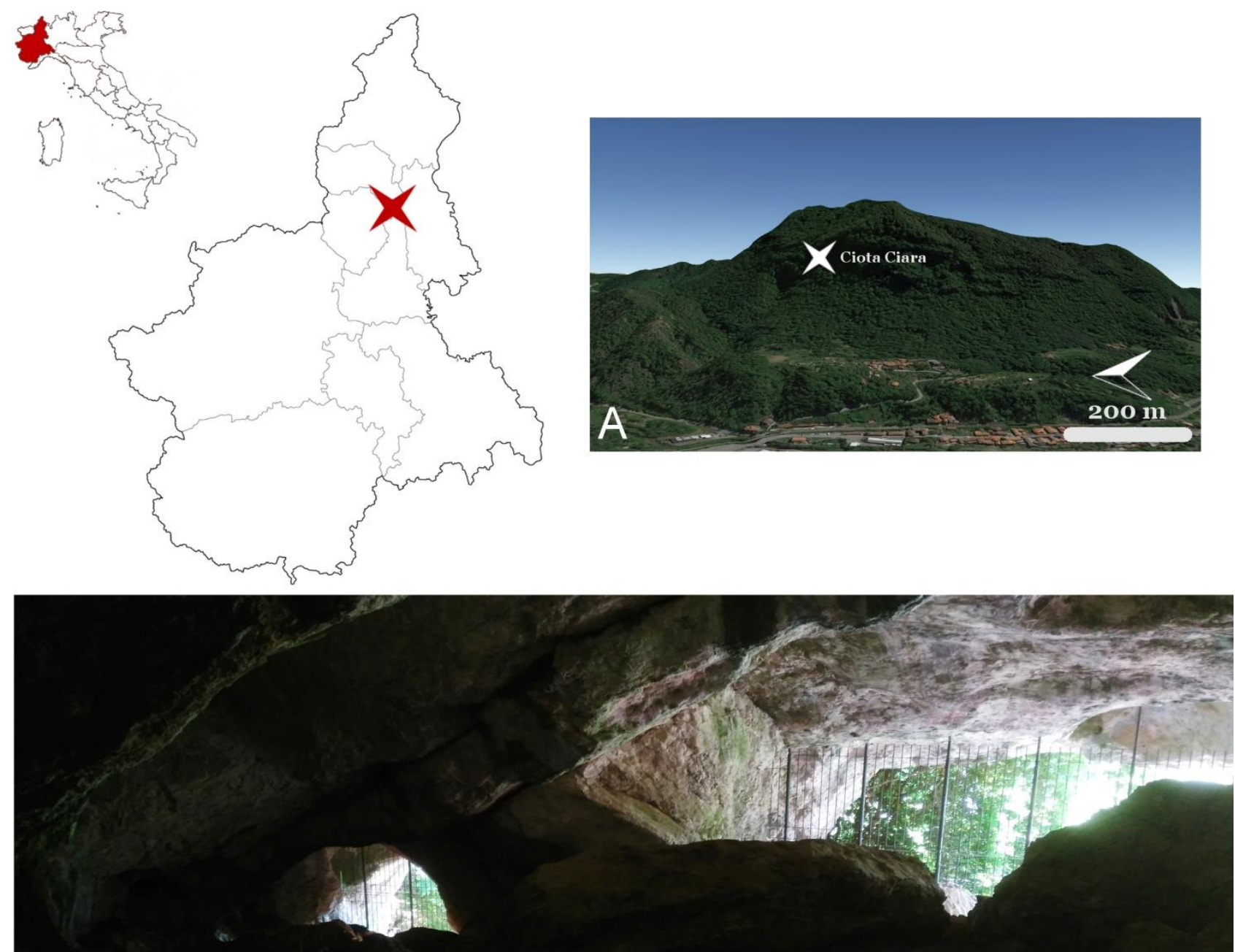

B

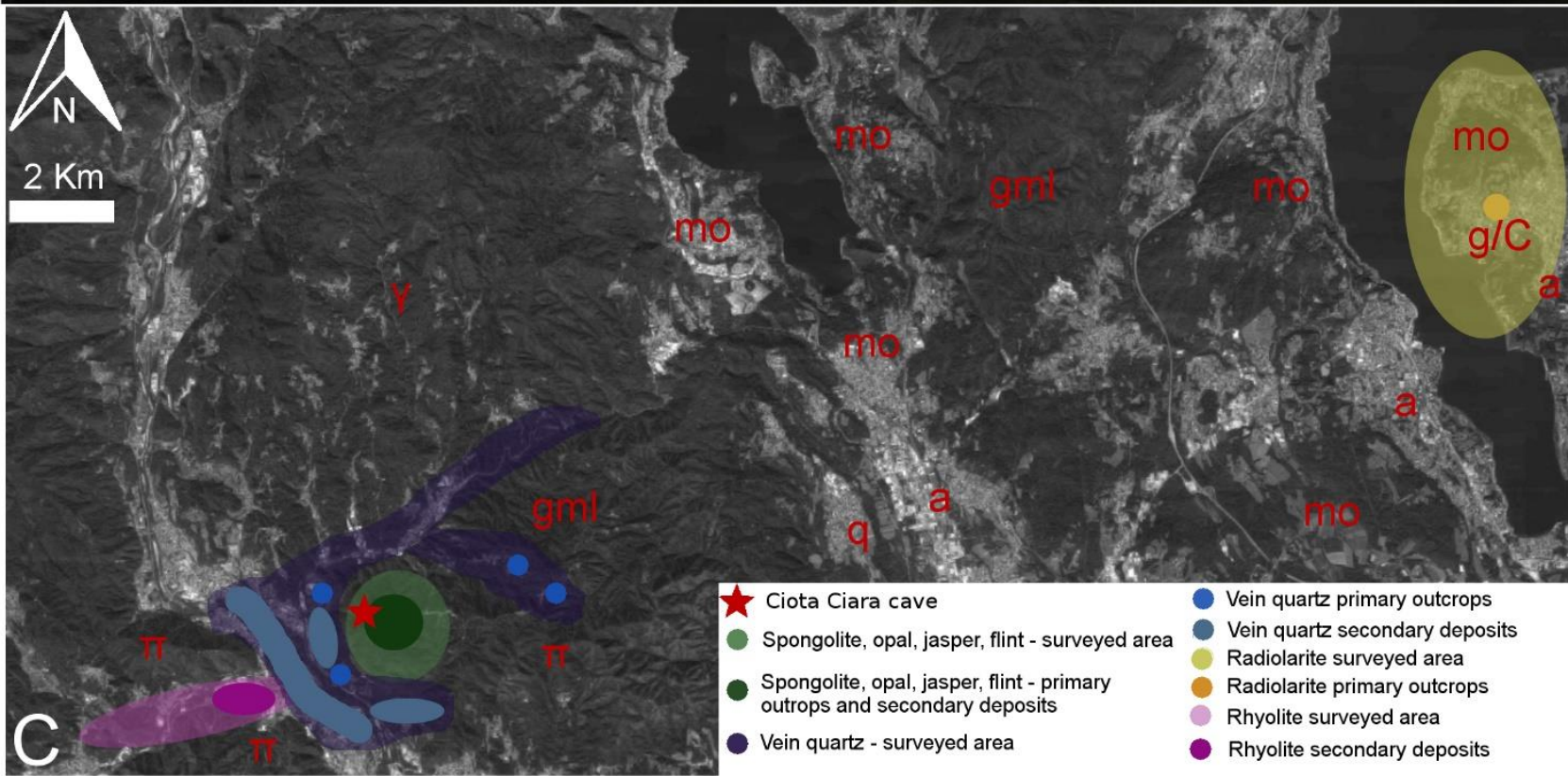


Fig. 2

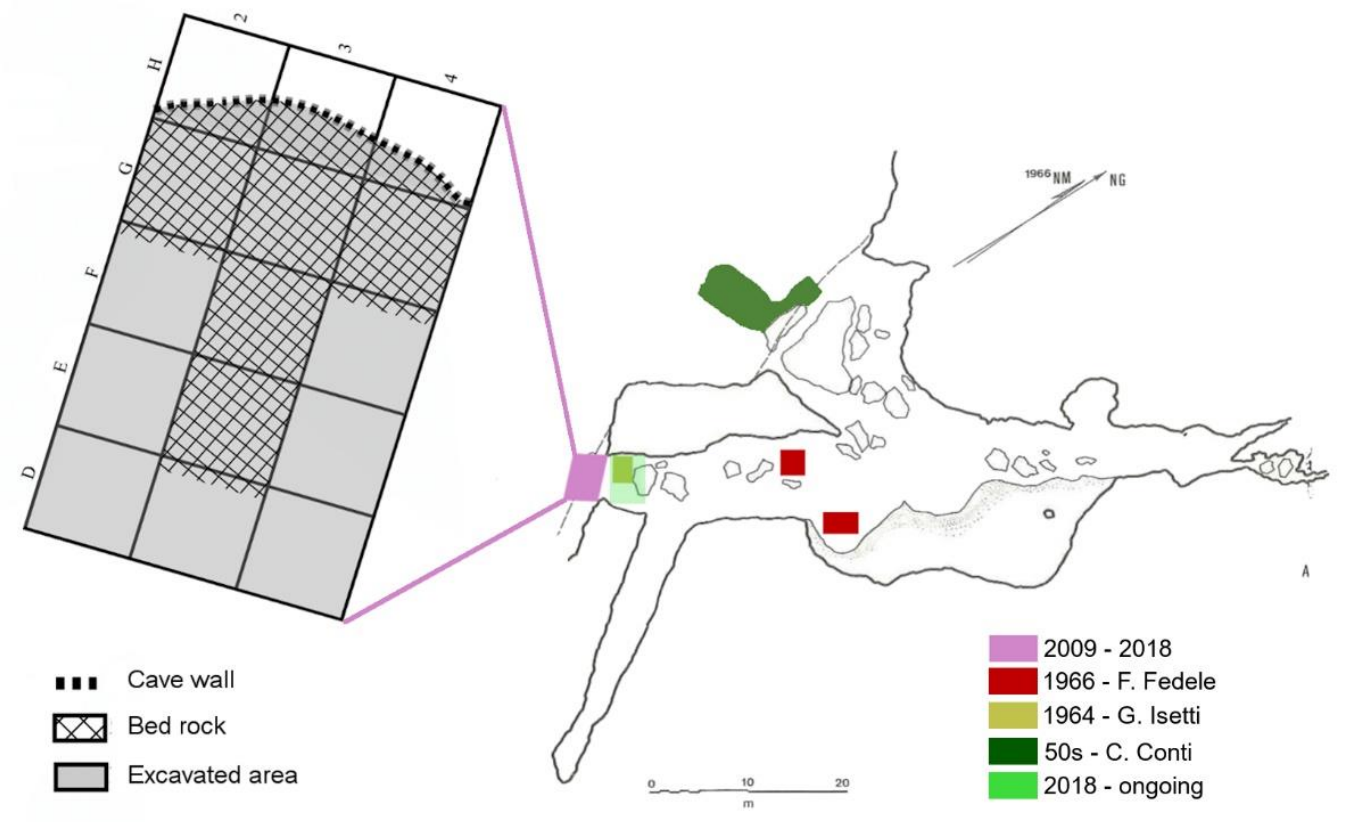

Fig. 3

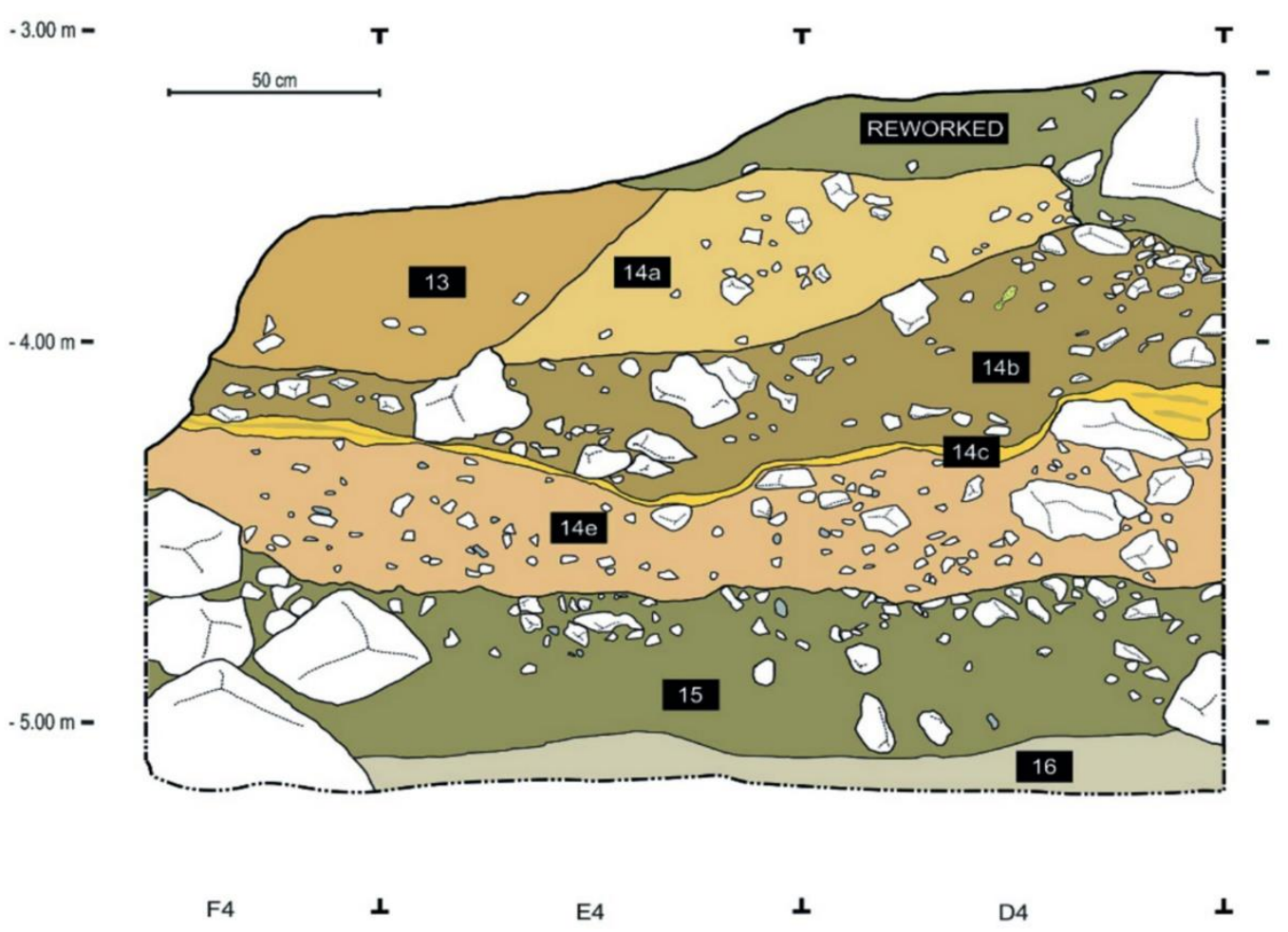


Fig. 4
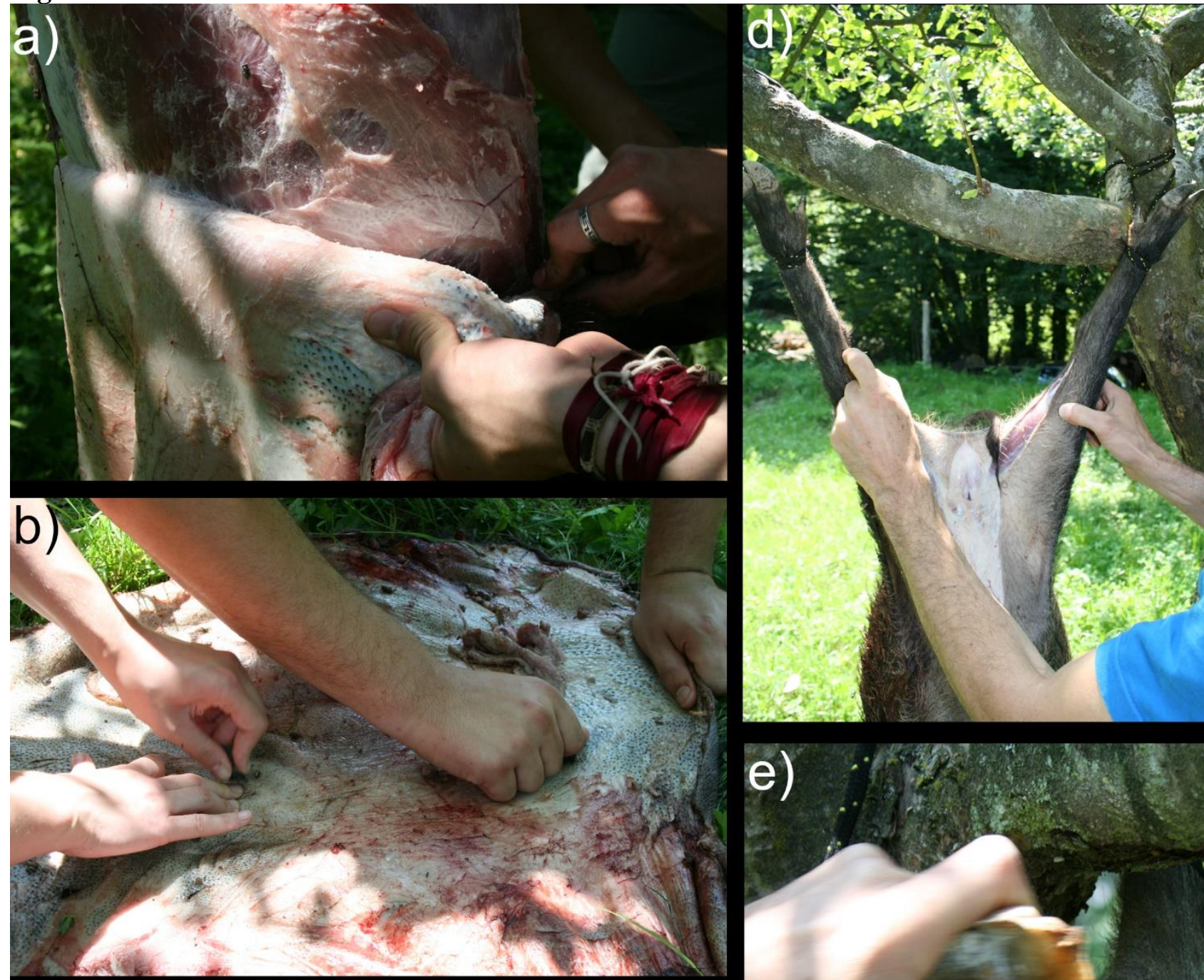

c) 8
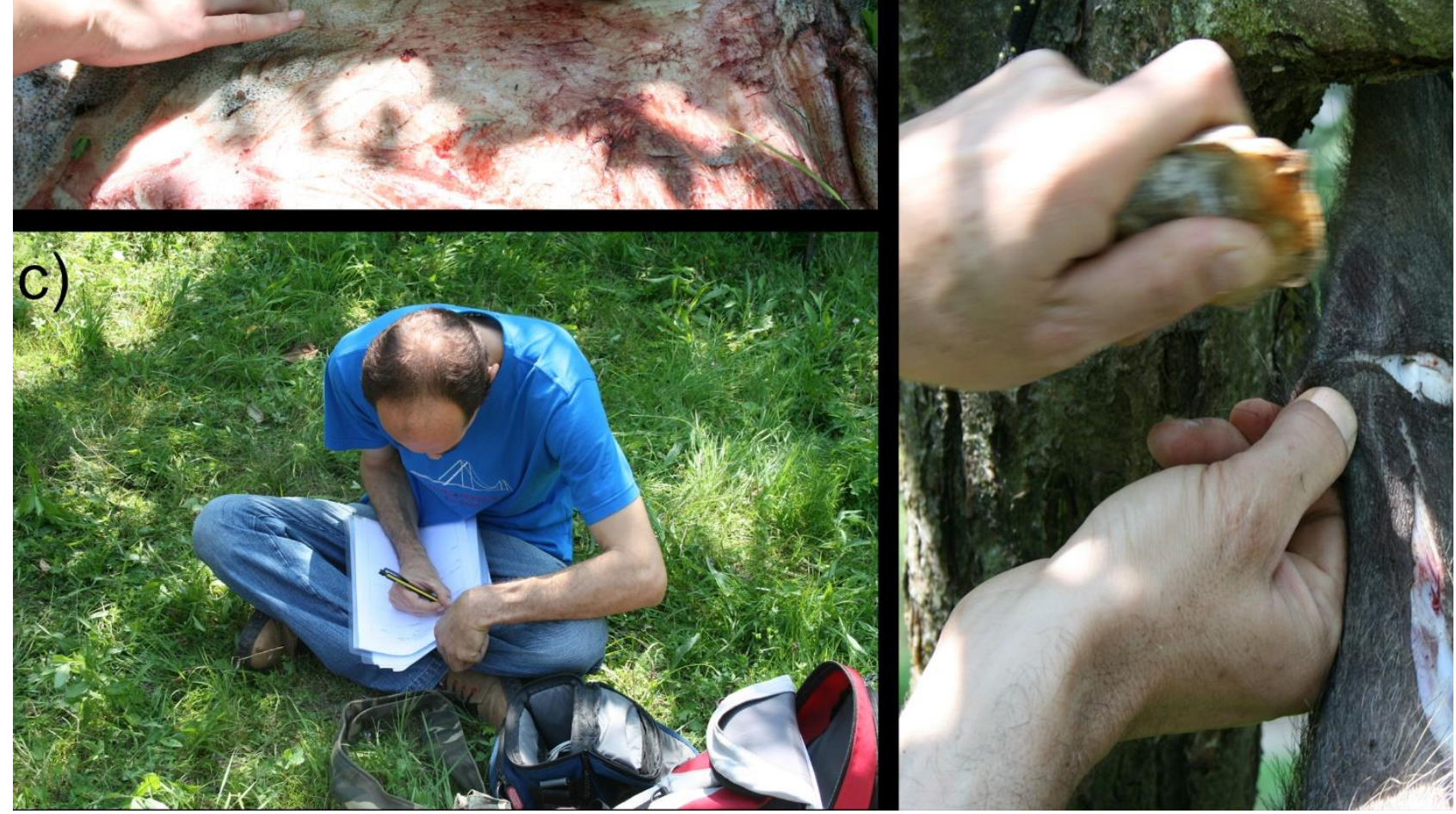
Fig. 5
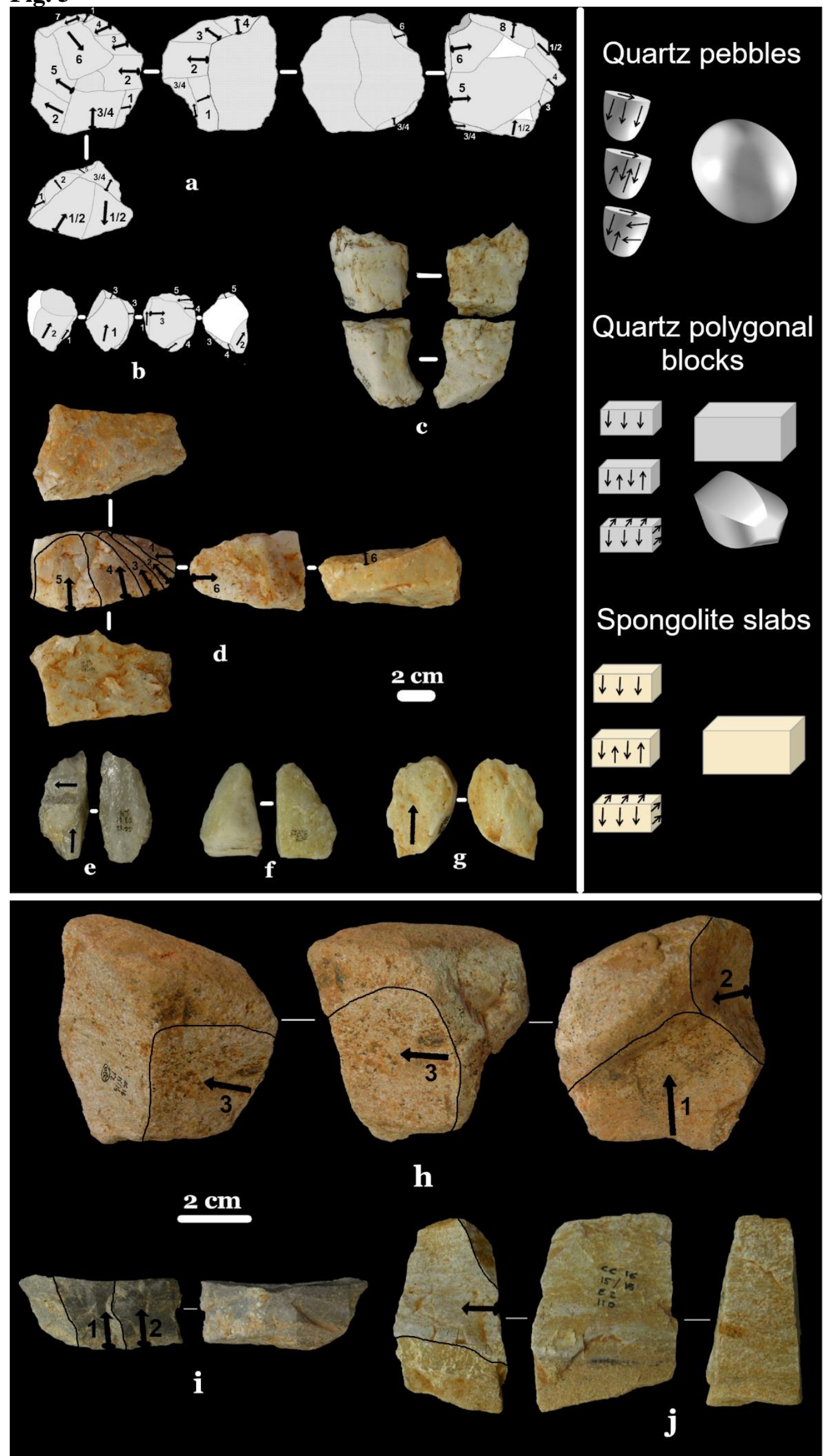
Fig. 6
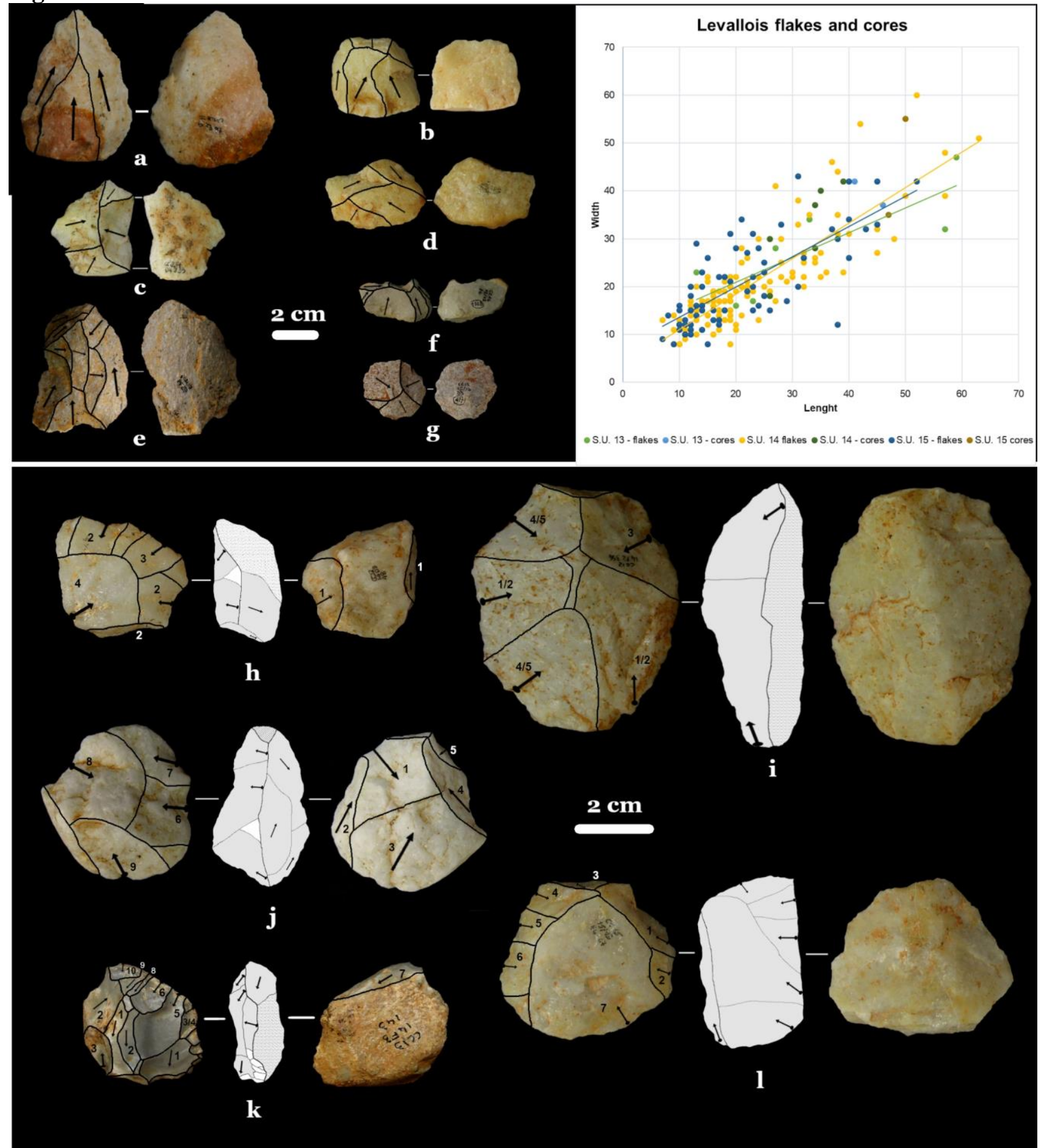
Fig. 7
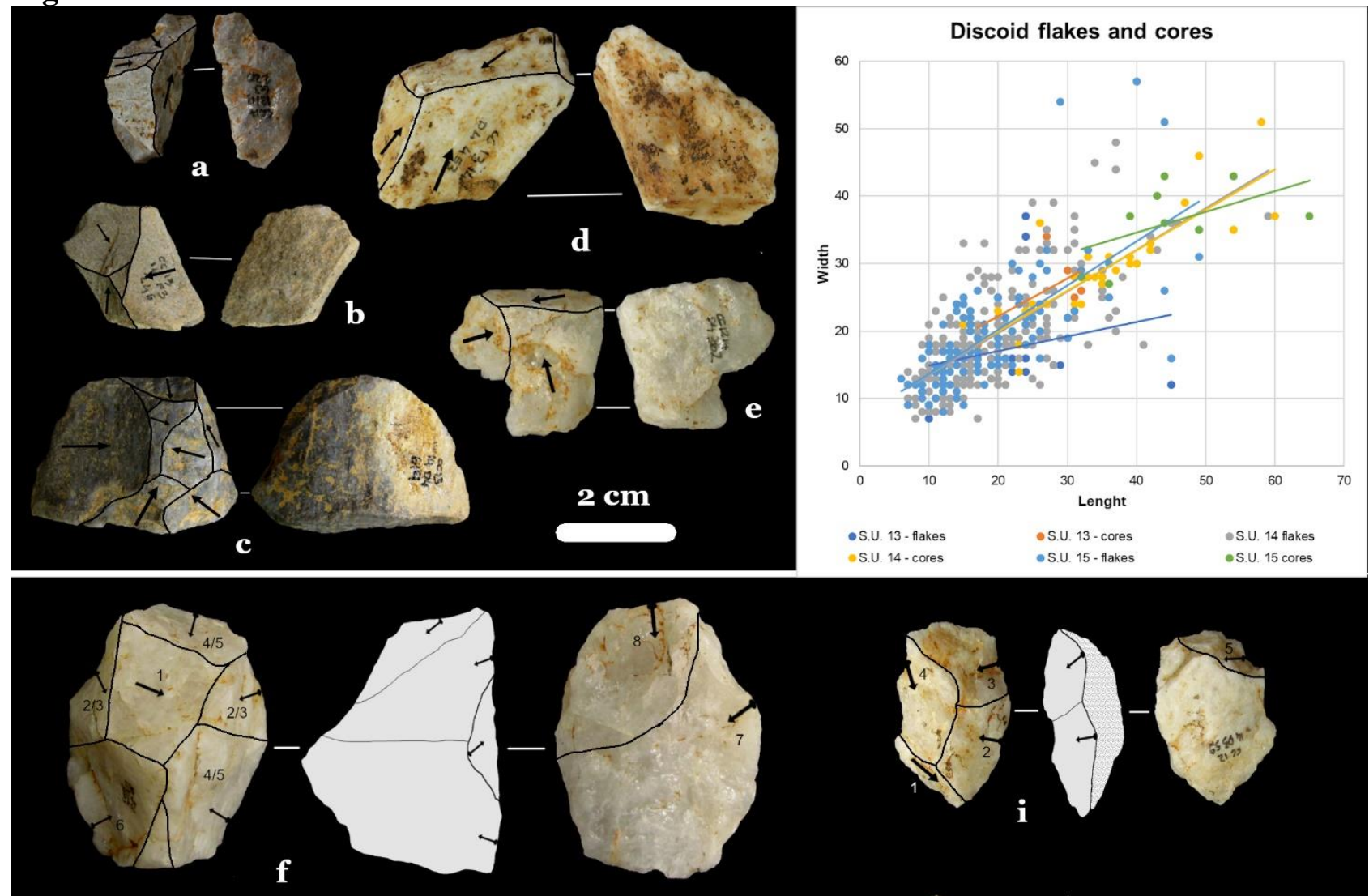

eSU. 15 cores

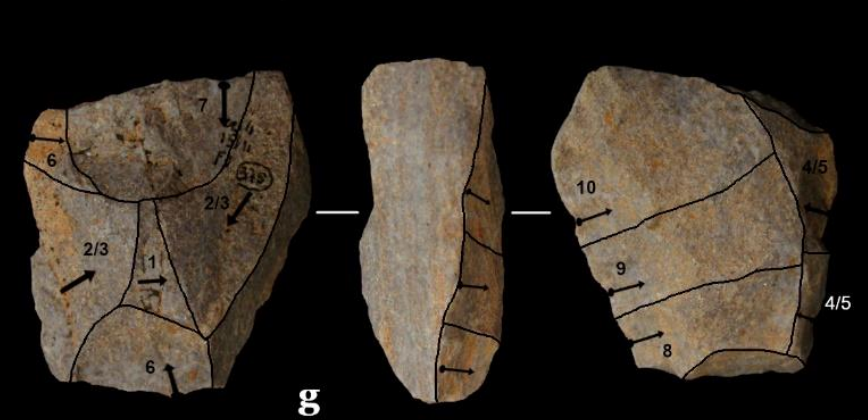

$2 \mathrm{~cm}$
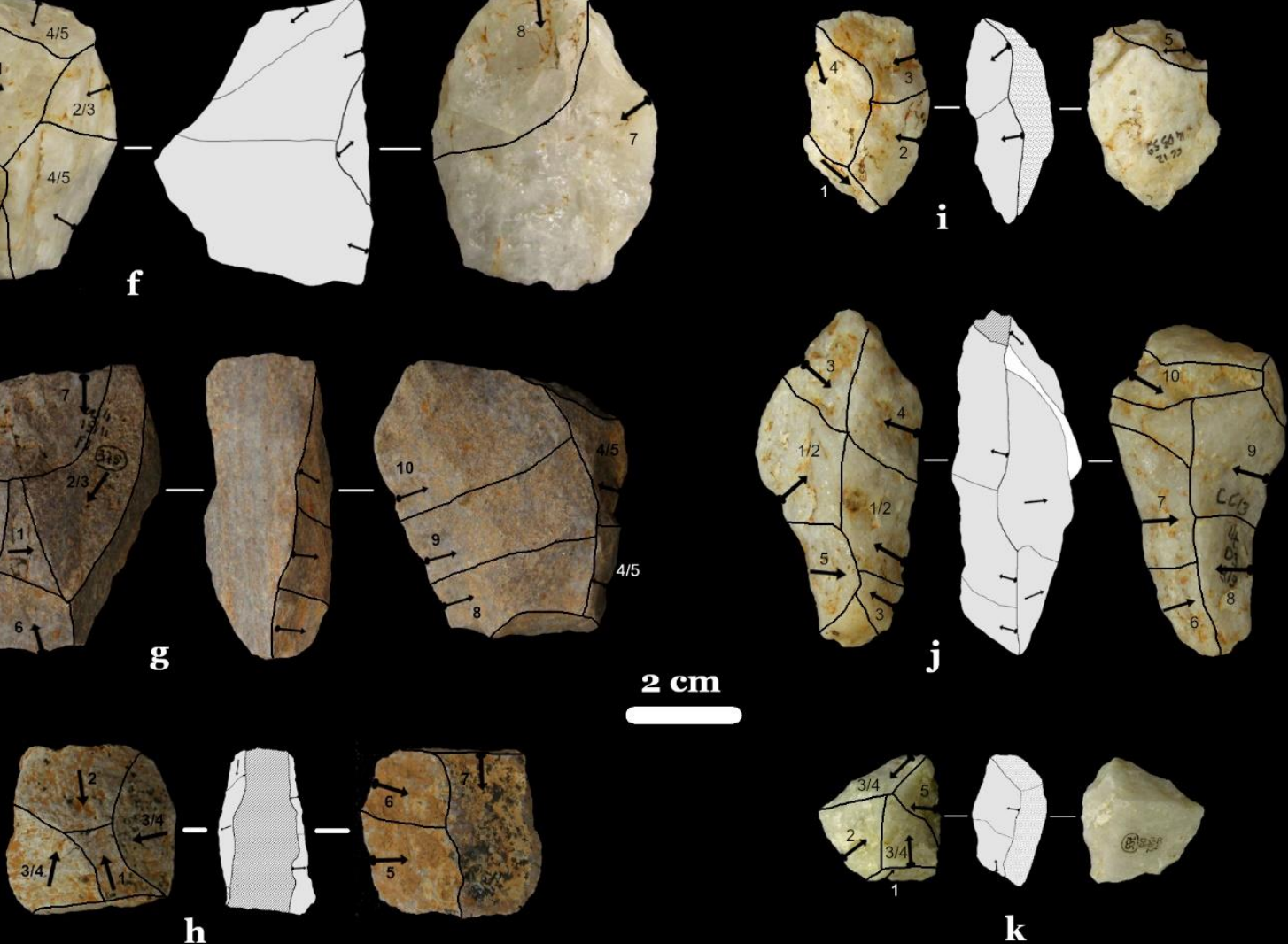
Fig. 8

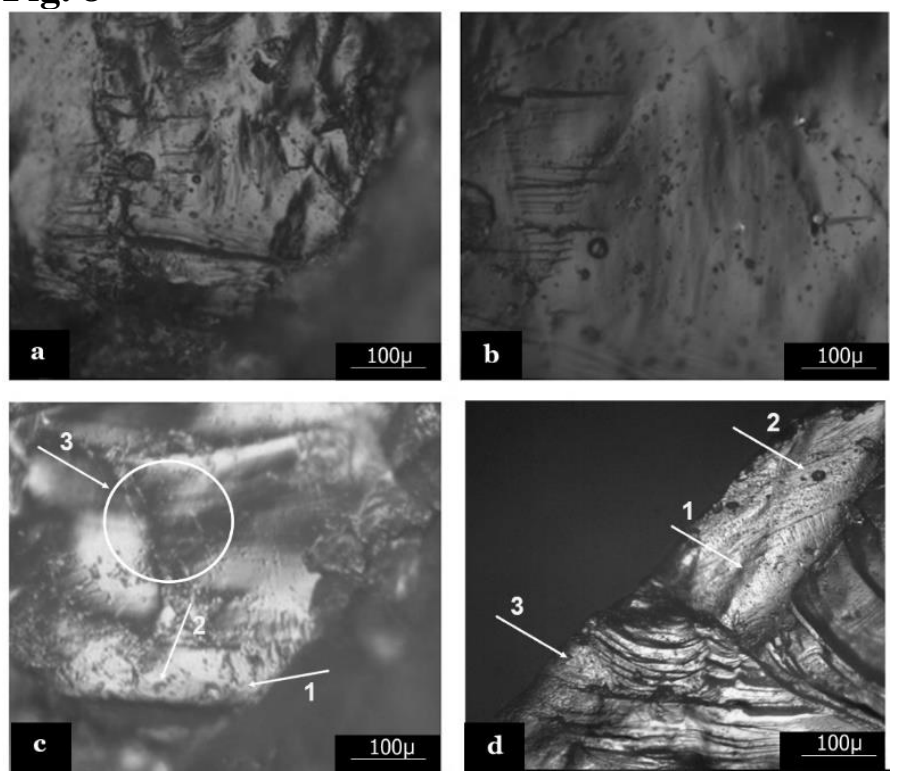

Fig. 9

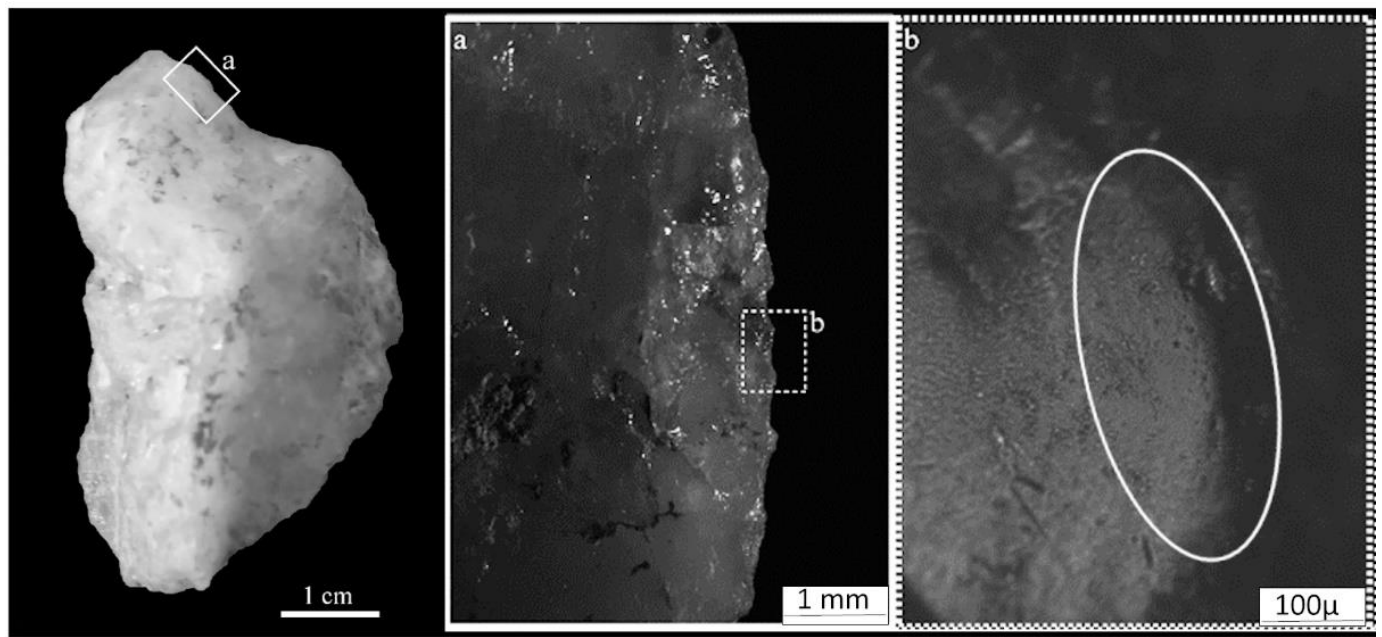

A

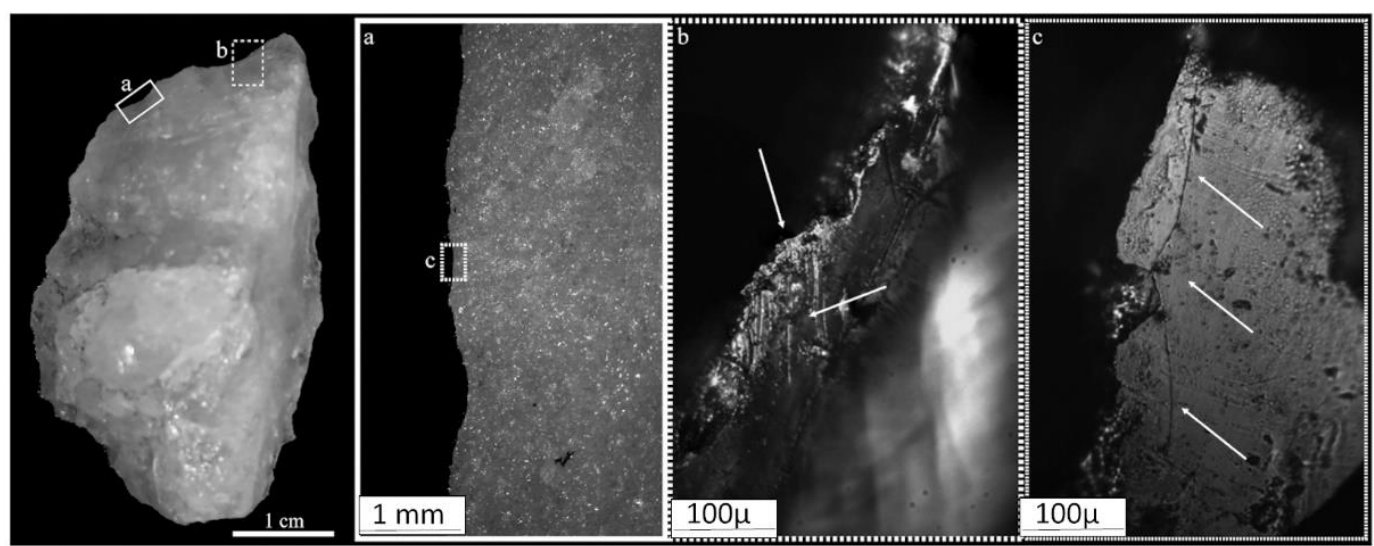

B 
Fig. 10
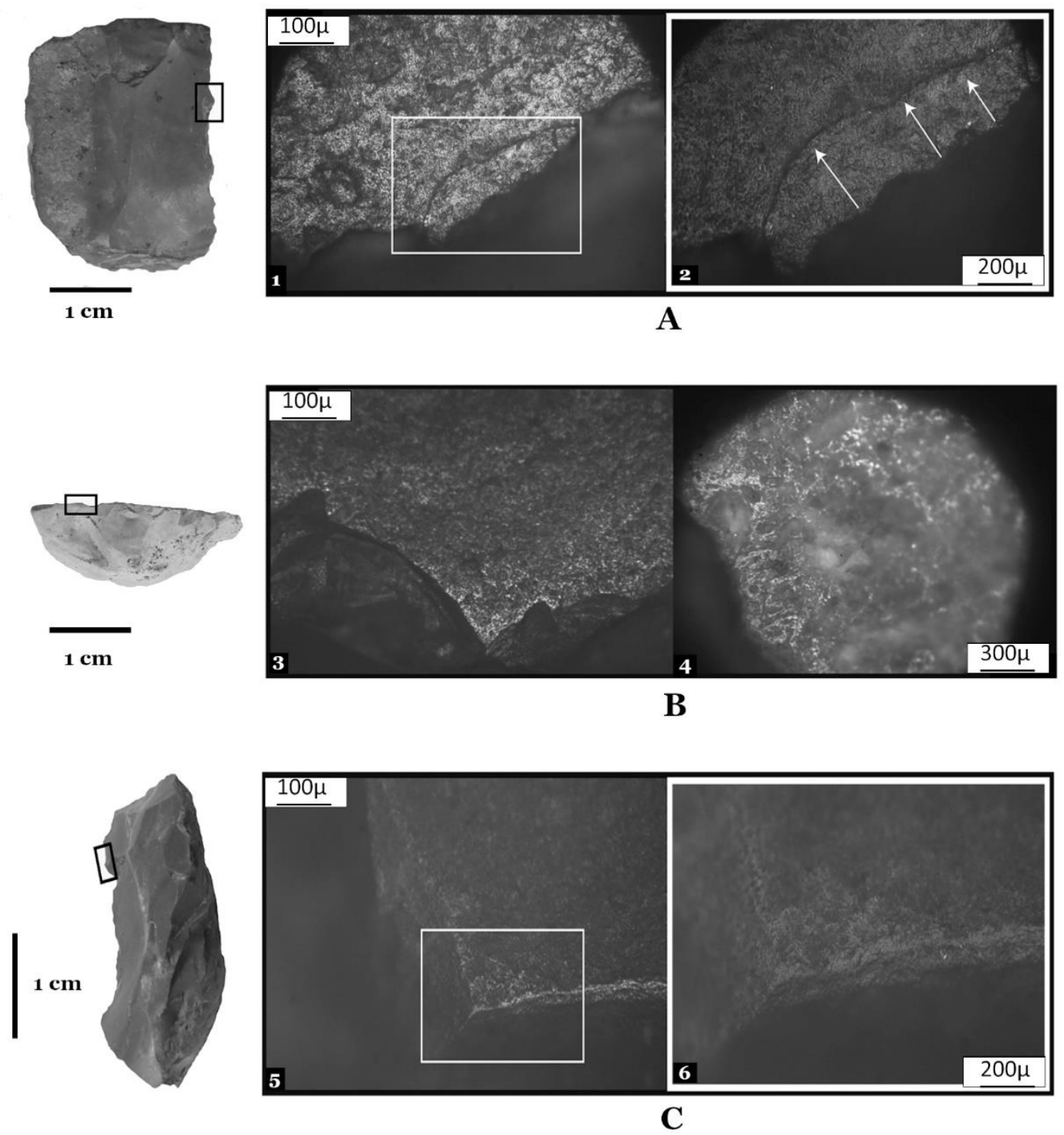